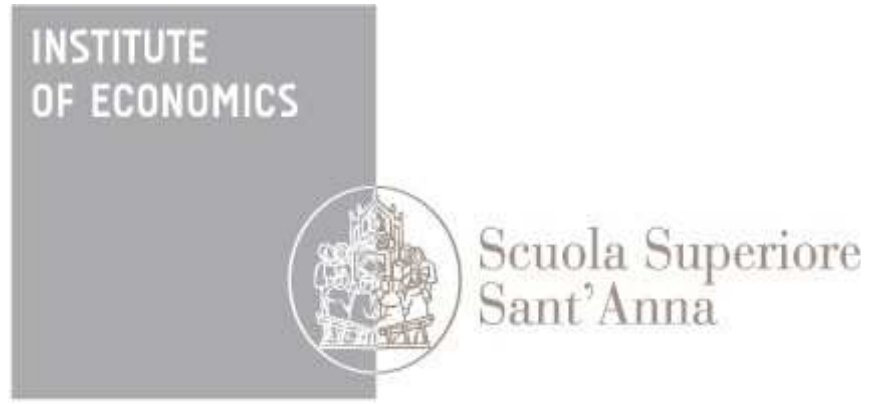

LEM | Laboratory of Economics and Management

Institute of Economics

Scuola Superiore Sant'Anna

Piazza Martiri della Libertà, 33 - 56127 Pisa, Italy ph. +3905088.33 .43$

institute.economics@sssup.it

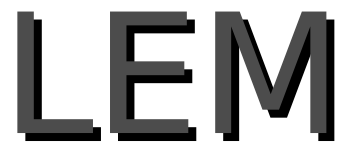

Working Paper Series

Technological Innovation and the Distribution of Employment Growth: a firm-level analysis

Flavio Calvino ${ }^{\circ}$

Institute of Economics, Scuola Superiore Sant'Anna, Pisa, Italy, and Paris School of Economics, France 


\title{
TECHNOLOGICAL INNOVATION AND THE DisTRIBUTION OF EMPLOYMENT GROWTH: A FIRM-LEVEL ANALYSIS*
}

\author{
Flavio Calvino ${ }^{\dagger a, b}$ \\ ascuola Superiore Sant'Anna \\ ${ }^{\mathrm{b}}$ Paris School of Economics - Université Paris 1 Panthéon-Sorbonne
}

\begin{abstract}
This work studies the firm-level relationship between different types of innovative activities and employment growth rates. Improving on previous investigations on the topic, it combines a dynamic panel analysis of the effects of different types of product and process innovation on employment growth with an outlook on the whole conditional employment growth distribution. Results show that product innovation - especially in terms of good new to the entire market - has a positive effect on employment growth. This role is likely to be particularly relevant for both fast-growing and shrinking firms. Process innovation appears instead to have less clear-cut dynamics, consistently with existing evidence. Among different types of process innovation, the introduction of novel auxiliary processes appears to be more positively linked with employment growth.
\end{abstract}

Keywords: Innovation; Employment growth; Dynamic panel methods; Quantile regression.

JEL classification: O30; L25; L60; C23; C21; J23.

\footnotetext{
${ }^{*}$ I am indebted with Angelo Secchi who provided useful comments and suggestions on different drafts of this work. I would also like to thank Stefano Bianchini, Giulio Bottazzi, Alex Coad, Chiara Criscuolo, Timothy DeStefano, Giovanni Dosi, François Fontaine, Maria Garcìa Vega, Georg Licht, Laura Magazzini, David Margolis, Orietta Marsili, Carlo Menon, Daniele Moschella, Alessandro Nuvolari, Bettina Peters, Federico Tamagni, Andrea Vezzulli, Maria Enrica Virgillito, Marco Vivarelli, participants in the Applied Microeconomics Seminar at Paris School of Economics, the 2016 International Schumpeter Society, and the SPRU 50th Anniversary Conference for their valuable insights. Support by the European Union Horizon 2020 research and innovation programme under grant agreement No. 649186 - ISIGrowth is gratefully acknowledged. Views expressed in this paper are my own, and do not necessarily reflect the official views of any institution with which I am affiliated. The usual disclaimer applies.

${ }^{\dagger}$ Institute of Economics, Scuola Superiore Sant'Anna, Piazza Martiri della Libertà 33, 56127 - Pisa (Italy) and Centre d'Economie de la Sorbonne - Maison des Sciences Economiques, 106-112 boulevard de l'Hôpital, 75647 - Paris Cedex 13 (France). E-mail address: f.calvino<at>sssup.it
} 


\section{Introduction}

This work studies the firm-level relationship between different types of innovative activities and employment growth rates. Improving on previous investigations on the topic - which mainly focus on the effect of a limited number of innovation indicators on the conditional average of the employment growth distribution - this study combines a dynamic panel analysis of the effects of different types of product and process innovation on employment growth with an outlook on the whole conditional employment growth distribution. Departing from conditional averages allows to focus on the role of innovation driving employment growth of fast-growing or shrinking firms, rather than substantially stable (average) ones, which is particularly important from a policy perspective.

The analysis is carried on using a panel of Spanish firms in the manufacturing sector from 2004 to 2012 (Panel Innovación Tecnológica). The results show that product innovation - especially in terms of goods new to the entire market - has a positive effect on employment growth. This role is likely to be particularly relevant for both fast-growing and shrinking firms. Process innovation appears instead to have less clear-cut dynamics, consistently with existing evidence. Among different types of process innovation, the introduction of novel auxiliary processes appears to be more positively linked with employment growth.

Robustly assessing the effects of technological innovation on employment growth is relevant for a number of reasons. Understanding whether technical change is beneficial or detrimental for employment is currently at the center of the policy discussions. The debate concerning the effects of technological innovation on employment growth is long standing and still enduring. The theoretical literature does not provide clear-cut evidence on innovation being ex-ante labour saving or labour destroying nor unequivocally establishes the extent to which different compensation mechanisms and indirect effects influence employment growth. Micro-econometric evidence tends to support the existence of a positive relation between innovation and employment, especially when R\&D or product innovation are adopted as proxies of innovative activity and more when high-technology sectors are the center of the analyses.

Limited availability of longitudinal innovation databases has constrained the extent to which the relationship between innovation and employment growth has been so far investigated. Furthermore, despite the role of patenting activity and $\mathrm{R} \& \mathrm{D}$ expenditures proved to be different for fast-growing and shrinking firms, comprehensive analysis of the effects of different kinds of innovation over the whole employment growth distribution has been limited, so far.

This study combines descriptive non-parametric analysis with different econometric techniques. The analysis on conditional averages is carried on in a dynamic panel GMM framework, following Arellano and Bover (1995), that allows to control for unobserved heterogeneity, possible endogeneity of innovation variables and dynamic effects in the employment growth process. Further analysis aimed at disentangling the role of technical change over the conditional employment growth distribution is carried on in a quantile regression framework.

This work is organized in seven sections. The following section further motivates and contextualizes the study in the framework of the theoretical and empirical debate; the third section describes the sample used and provides preliminary descriptive evidence; the fourth section presents the econometric model and the results of the empirical exercises; in the fifth section a number of robustness checks are carried on; the sixth section further discusses the results, the implications and limitations of this study; the final section concludes. 


\section{Literature background and motivation}

The debate on the effects of technical change on employment growth dates back to the Luddites, includes the Ricardian conceptualization of technological unemployment (Ricardo, 1817), the Keynesian predictions on "mankind solving the economic problem in the long run" via technological progress (Keynes, 1931), and culminates in the discussions on the widespread effects of automation and robotization on western societies (see for instance Michaels and Graetz, 2015). This section, after a theoretical introduction, focuses on the empirical contributions that examine the effect of innovation - in its different declinations - on employment growth at firm level, further motivating this study. It builds upon the work by Calvino and Virgillito (2016), to which we point the reader for further details and discussion.

\section{$2.1 \quad$ Theoretical framework}

The relationship between innovation and employment growth, i.e. the extent to which technological progress is labour saving, is a key issue in economics both from a theoretical and empirical perspective. The theoretical literature does not provide clear-cut evidence on innovation being ex-ante labour saving or labour destroying nor unequivocally establishes the extent to which different compensation mechanisms and indirect effects are in place (see Vivarelli, 2014, Spiezia and Vivarelli, 2002, Pianta, 2005 for further details). The theoretical debate, in fact, opposes school of thoughts that argue in favour of the effectiveness of self-equilibrating compensation mechanisms, that automatically absorb the effects of innovation on employment leading to an asymptotic equilibrium of the economic system, to scholars that frame innovation as a complex phenomenon, with manyfold counteracting effects due to interaction of heterogeneous agents.

One of the key issues to take into account when examining the effects of innovation on employment growth is the distinction between different kinds of innovative activities. In particular, as pointed out by Dosi (1984, p. 104), "product innovation of one sector are often process innovation for other sectors which are using them. The distinction nonetheless is theoretically fruitful". Product innovation is in fact directly associated with a positive effect on employment, inducing employment growth via the increase of the demand for the new products. However, this direct positive effect is limited if the new products substantially replace the sales of old ones (cannibalization effect). Process innovation is instead directly associated with negative effects, via the increase in efficiency that, at output fixed, is linked to job destruction. A number of indirect effects, part of which are labelled by the literature as compensation mechanisms, act in opposite direction. Namely, the positive effect of product innovation is limited by the extent to which product and process innovation strategies are complementary. The negative effect of process innovation may be instead re-equilibrated via different channels (namely, decreasing prices, increasing labour demand following declining wages in a competitive labour market, increasing investments or increasing income) 1 The empirical validity of such compensation mechanisms is still debated. However, some studies provide empirical support to the mechanism via decrease in prices, which relates process innovation to an increase in firm-level demand due to the reduction in production costs and prices (Harrison et al., 2014, Simonetti et al., 2000, Vivarelli, 1995).

Despite many theoretical (and empirical) studies emphasize the Schumpeterian distinction between product and process innovation, the building blocks of these two kinds of innovation are rarely discussed in depth. Reference definitions come from the OECD Oslo manual (OECD and Eurostat, 2005). Product innovation includes both new or significantly improved goods and services. Process innovation encompasses, instead, new or significantly improved methods of production, delivery methods, changes in techniques,

\footnotetext{
${ }^{1}$ See Calvino and Virgillito (2016) or Vivarelli (2014) for in-depth discussions on these mechanisms.
} 
equipment or software, and can be apt to quality increase or cost decrease. Different building blocks of product and process innovation can have specific effects on employment dynamics. For instance, the introduction of a new delivery system could require more workers, despite being a process innovation. Furthermore, the role of software and information systems can be ambiguous (and is widely discussed in the literature that debates on skill-biased technical change, see for instance Autor et al. 2003).

\section{$2.2 \quad$ Empirical evidence}

Empirical evidence on the effects of innovation on employment growth is wide. For the purpose of this work, let us focus on some of the most recent firm-level studies, and especially on the ones analysing the role of different kinds of innovative activities.

An important caveat which needs to be kept in mind (and will be further discussed in the penultimate section of this work) is the relevance of the level of aggregation at which analyses are carried on. More specifically, it is not obvious to interpret a positive effect of innovation on employment growth at firm-level as evidence of the fact that innovation induces a general increase in employment at industry (or society) level. As a matter of fact, market selection, business stealing and market expansion effects, firm entry and exit, relocation of activities, may induce completely different dynamics at higher levels of aggregation (see Calvino and Virgillito, 2016 for further details).

Micro-econometric evidence tends, to a certain extent, to support the existence of a positive relation between innovation and employment growth, especially when R\&D or product innovation are adopted as proxies of innovative activity and more when high-technology firms are the center of the analyses (see Harrison et al., 2014, Evangelista and Vezzani, 2012, Coad and Rao, 2011 and Hölzl, 2009 among the others). Empirical estimates of the effects of process innovation on the conditional average of the employment growth distribution are instead ambiguous (see for instance Harrison et al., 2014, on four countries including Spain; Evangelista and Vezzani, 2012 on a wider number of countries; Greenan and Guellec, 2000 on France).

A limited number of contributions analyze the relationship between product and process innovation and employment growth using panel data. Lachenmaier and Rottmann (2011) investigate the role of product and process innovation by using a panel dataset stemming from the Ifo Innovation Survey and covering manufacturing firms in Germany for more than 20 years (1982-2002) by means of a dynamic GMM-SYS framework. In contrast with previous literature, Lachenmaier and Rottmann (2011) find that the effect of process innovation tends to be higher in magnitude with respect to the one of product innovation 2 In a similar vein, using a long Spanish panel between 1990 and 2008, Triguero et al. (2014) further investigates whether firms show heterogeneous responses in employment growth depending on the degree of persistence of their different innovative activities, comparing SMEs and larger firms. Similarly to Lachenmaier and Rottmann (2011), they support the existence of a positive link between persistent process innovation activities and employment, with the magnitude of such effect increasing with the time lag considered, especially for SMEs, while, no significant effect is found for persistence in product innovation. Finally, Peters et al. (2014) use German data from the Mannheim Innovation Panel between 1994 and 2012. They adapt the framework proposed by Harrison et al. 2014 accounting for individual heterogeneity in a fixedeffects framework, suggesting a positive role of product innovation and very limited displacement effects of process innovation.

It has been clear, so far, that both theoretical and empirical insights suggest that different types of innovation may have different impacts on employment.

${ }^{2}$ The same authors provide similar findings in a previous study on the same data, exploiting static panel methods (see Lachenmaier and Rottmann, 2007) 
Despite the role of patenting activity and $R \& D$ expenditures proved to be different for fast-growing and shrinking firms (see for instance Coad and Rao, 2011, Falk, 2012, Segarra and Teruel, 2014, Coad et al. 2016), comprehensive analysis of the effects of different kinds of innovation over the whole employment growth distribution has been limited, so far. In this respect, Herstad and Sandven (2015) link Norwegian CIS2008 data with business register, before and after the innovation survey, ordering into categorical classes firms with different growth rates 3 Their results suggest a certain degree of autocorrelation in growth rates, and a correlation between ex-ante growth and innovative activity, which further strengthen employment growth when both product and process innovations are introduced. Furthermore, Herstad and Sandven (2015), challenging common empirical findings, suggest that process innovation is significantly associated with positive ex-post employment growth, especially for firms in the top of the distribution. On the other hand, Zimmermann (2009) analyses the relationship between product and process innovation and employment growth, focusing exclusively on small and medium enterprises in Germany. Zimmermann (2009) estimates a quantile regression model in the context of a dynamic labour demand equation, investigating the effect of product and process innovation (occurred between time $t-2$ and $t-4)$ on the two-year average employment growth rate distribution. The findings suggest that innovation (especially process innovation) has a positive effect of employment for both growing and shrinking SMEs in Germany 4

However, generalizing in this context country-specific findings has proven not obvious. Hölzl (2009), for instance, suggests that innovation success and R\&D intensity are crucially important for high-growth SMEs in countries closer to the technological frontier (despite a decrease in magnitude of such effects in the very top 5\%), than in countries further away. Moreover, high-growth SMEs look more innovative than non-high-growth SMEs exclusively in economies which are not too far from the technological frontier.

This work focuses on the firm-level impact of innovation output, measured in terms of product and process innovation (and their declinations) on employment growth in the Spanish manufacturing sector. Related analyses come from the strand of empirical literature that studies the effect of innovation on growth using different innovation proxies, or which studies the effect product and process innovation on sales growth. Coad et al. (2016) focuses, for instance, on the impacts of R\&D (and not of innovation output) on the sales, employment and productivity growth of Spanish firms, while Bianchini et al. (2016) take instead a multi-dimensional approach to the analysis of the growth process of Spanish firms in terms of sales (and not employment).

\section{Data and descriptive analysis}

The analysis is carried on using the Spanish Technological Innovation Panel (Panel Innovación Tecnológica, henceforth PITEC) between 2004 and 2012. PITEC is the result of a joint effort by the Spanish National Statistical Institute (INE), the Spanish Foundation for Science and Technology (FECYT) and the Spanish Foundation for Technical Innovation (COTEC) 5 The key characteristics that distinguishes PITEC from

\footnotetext{
${ }^{3}$ They investigate the relationship between employment growth prior to innovative activity, innovation output, and growth after the innovation event. They first assess the link between different types of innovation and employment growth prior to the period for which they have CIS data (i.e., from 2004-2006). Subsequently, they categorize firms in 6 categorical classes, (ordering them according to their employment growth rate calculated in log differences between 2006 and 2010) and assess, by means of ordered logit estimation, how such categorical variable is associated with ex-ante growth and (product or process) innovation. Finally they propose binary logistic regression to investigate the probability to achieve growth above particular thresholds. On the side of their main results by means of multivariate probit and ordered logit, they briefly discuss quantile regression as an alternative estimation strategy which provides consistent results to those presented in the core of their work.

${ }^{4}$ With stronger effects on high-growth SMEs mostly in the case of process innovation.

${ }^{5}$ We use the anonymized version of the database, which has been widely used in the literature. Details on the anonymization procedure by individual ranking applied to quantitative variables (including employment) in PITEC are presented by López
} 
the majority of Innovation Surveys (such as the CIS, collected by Eurostat) are its longitudinal nature and the presence of a considerable number of different innovation indicators. Indeed, since 20046 systematic data collection efforts allow to follow the same firms over time. PITEC data have been recently used to the study of innovative activity and growth in recent years (see among the others Segarra and Teruel, 2014, Coad et al. 2016 or Bianchini et al., 2016). A summary of the variables used in this work is presented in the following subsections. Both innovative and non-innovative firms populate the sample, which combines representative sub-samples of small firms (with less than 200 employees) and larger businesses (more details on representativeness can be found in the Appendix).

\subsection{Sample and Panel composition}

The sample period analyzed ranges between 2004 and 2012. The focus is limited to the manufacturing macro-sector 7 Due to changes in industry classification (from CNAE-93 to CNAE-09 between 2008 and 2009) a probabilistic industry converter has been implemented - in order to properly control for sector invariant effects - calculating weights based on observations for which both industry classifications are available. Details are provided in Appendix. The analysis focuses on organic employment growth 8

The panel includes 6,561 firms. Note that 568 firms that appeared for one year only have been dropped. For about 50 percent of the firms all time lags are observed. Most firms (almost 75 percent) are observed for 6 consecutive periods or more. A limited number of gaps are found in the panel (about 1.8\% of the sample). Descriptive statistics are presented in Table A1 in the Appendix ${ }^{9}$

\subsection{Variables of interest and preliminary evidence}

The main variables that we use to study the relationship between employment growth and innovation are presented hereafter.

\subsubsection{Employment growth}

The response variable of our interest is firm-level employment growth $\left(G_{i, t}\right)$. Let $E_{i, t}$ be the employment of firm $i$ at time $t$, then employment growth is defined as:

$$
G_{i, t}=\log \left(E_{i, t}\right)-\log \left(E_{i, t-1}\right)
$$

A kernel density estimate of the employment growth distribution is presented in Figure 1 Note that the $\mathrm{y}$ axis is reported on a logarithmic scale. The fat tails of the distributions are consistent with corroborated empirical evidence (see for instance Bottazzi and Secchi, 2006). Its resemblance to a tentshape in logarithmic scale might suggest that a Laplace processes can be a first-order approximation to describe the empirical densities. However, a significantly high concentration of "zeros" is evident. This is possibly linked to the discrete nature of employment which, when measured in head counts as in this case,

(2011), who shows empirically that it produces reliable results (see also Schmid and Schneeweiss, 2009 for further theoretical discussion).

${ }^{6}$ Note that data collection effort starts the year before. In 2003, however, firms with less than 200 employees are significantly under-represented. This year is therefore excluded from the analysis, similarly to other studies based on PITEC data.

${ }^{7}$ CNAE-1993 industry codes from 15 to 37 and CNAE-2009 industry codes from 10 to 33.

${ }^{8}$ In the survey a variable records unusual patterns in employment due to, for instance, mergers, acquisitions or liquidations (Indicador de incidencia en el empleo). Only firms without contingencies have been analysed. They correspond to about $99.4 \%$ of the sample.

${ }^{9}$ The number of observation used for estimation reduces due to the inclusion of the lagged dependent variables and due to some missing in the age variable detailed in Appendix. 
Figure 1: Employment growth distribution

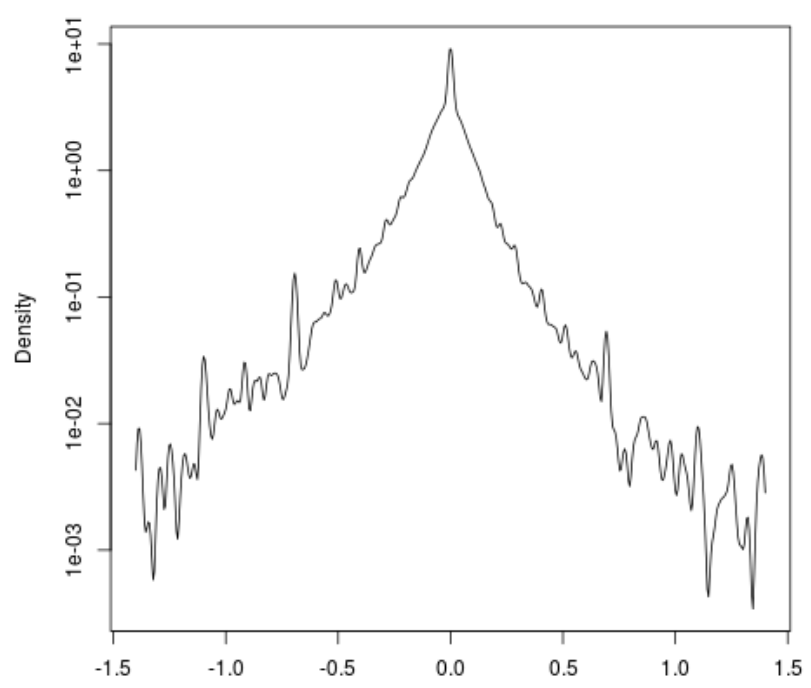

Notes: the graph shows a kernel density estimate of the employment growth distribution. Kernel densities are computed using an Epanechnikov kernel. The y axis is in logarithmic scale. The distribution is reported between -1.4 and 1.4.

Figure 2: Employment growth distribution - Innovators vs. non-innovators

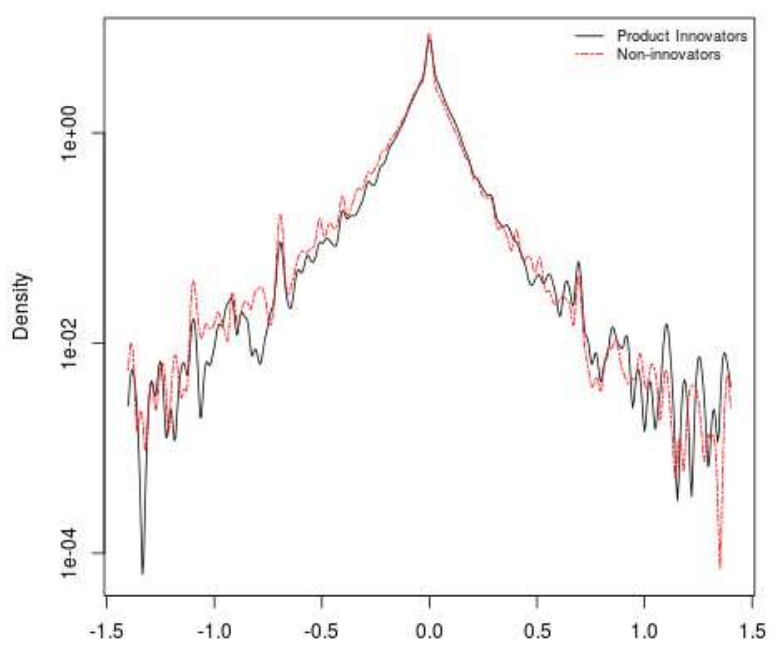

(a) Product vs. non-product innovators

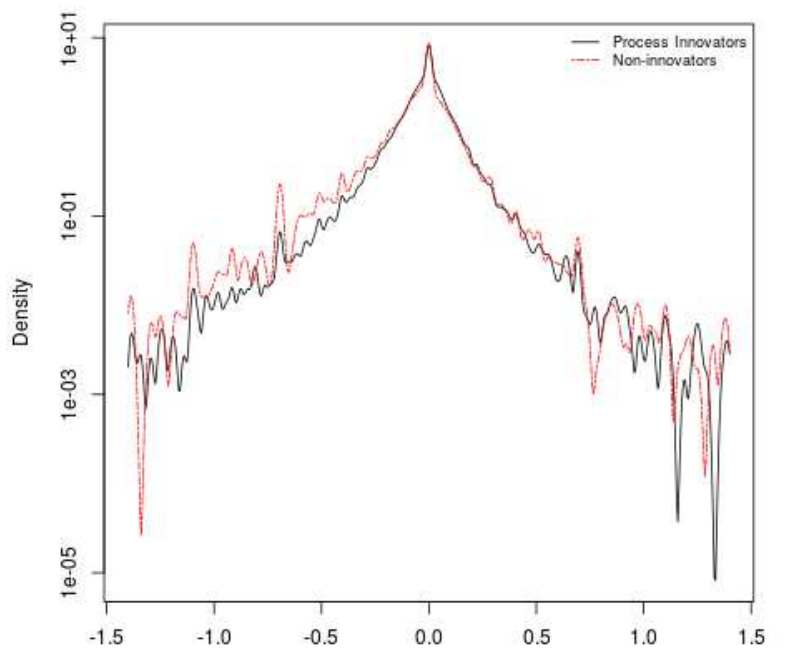

(b) Process vs. non-process innovators

Notes: the graphs show a kernel density estimate of the employment growth distribution for innovators (new-to-the market product innovation and process innovation) and non-innovators. Non-innovators are reported in a different color. Kernel densities are computed using an Epanechnikov kernel. The y axis is in logarithmic scale. The distribution is reported between -1.4 and 1.4 . 
is an integer number. Further investigation would be necessary to corroborate this feature of employment growth distributions.

\subsubsection{Innovation variables}

The PITEC database allows to have an in-depth look at the specificities of product and process innovation activities. The explanatory variables used to investigate the effects of product versus process innovation are presented hereafter ${ }^{10}$

Product Innovation Dummy equal to 1 if the firm introduces new or significantly improved products and zero otherwise. We focus on product innovations which are new to the entire market, as they are more likely to represent a genuine innovative step. We will refer to this variable as ProdInn. The product innovation variable can be split in the following components.

1. Goods: dummy variable identifying whether product innovation consist of a new or significantly improved good.

2. Services: dummy variable identifying whether product innovation consist of a new or significantly improved service.

Process Innovation Dummy equal to 1 if the firm introduces new or significantly improved processes and zero otherwise. We will refer to this variable as ProcInn. Different types of process innovation can be distinguished, as follows.

1. Methods: dummy variable that identifies the case in which process innovation consists on new or significantly improved production methods.

2. Logistics: dummy variable that identifies the case in which process innovation consists on new or significantly improved logistics, delivery or distribution systems.

3. Auxiliary processes: dummy variable that identifies the case in which process innovation consists on new or significantly improved auxiliary processes (such as maintenance, IT, purchasing or accounting processes).

Descriptive statistics and kernel density estimates of the distribution of firm-level employment growth by innovation status are presented in Table A4 and in Figure 2, respectively. Particularly when using the process innovation proxy, a concentration of non-innovative firms in the left tail of the support of the employment growth distribution is evident. This is consistent with previous findings presented by Bianchini et al. (2016) on the sales growth distributions of Spanish firms.

\subsubsection{Age}

Differently from other innovation surveys, PITEC allows to take into account the age dimension, which we include in the analysis. Further details concerning how the age variable was built and its missing values are presented in the Appendix. A histogram of the age distribution is presented in Figure 3 . The exponential decay of the age distribution over most of its support suggest that a geometric law could be an acceptable first-order approximation to describe its empirical distribution ${ }^{11}$

However, consistently with most recent empirical evidence (see for instance Coad, 2010, Coad et al. 2016 and Barba Navaretti et al. 2014), deviations from the geometric fit are more evident for youngest

\footnotetext{
${ }^{10}$ As in most innovation surveys, innovation variables refer to innovative activities carried on by the firm between time $t-2$ and $t$.

${ }^{11}$ Recent literature characterizes the age distribution as exponential, while we prefer to keep the discrete nature of the age variable.
} 
Figure 3: Age distribution

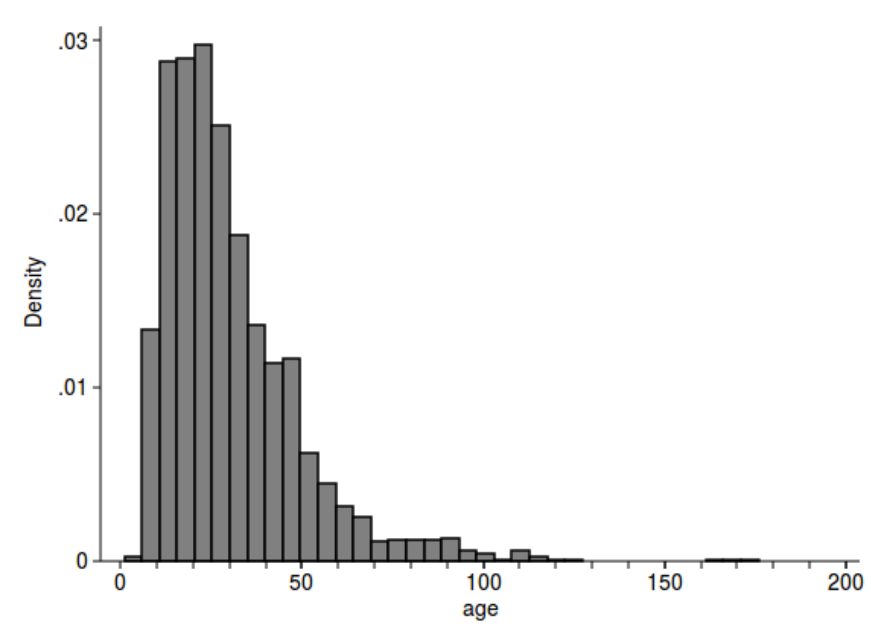

Notes: the graph shows the histogram of the age distribution in 2011 over 36 bins. Qualitatively similar patterns hold for other years in the sample.

and oldest groups of firms. As a matter of fact, it is possible to note that the modal age in the 2011 sample presented in the figure is about 20 year, suggesting a deviation from the geometric fit, which would predict the modal age to equal the youngest group of firms in the sample.

\section{Econometric analysis}

The starting point of the econometric analysis is the traditional Law of Proportionate Effect (Gibrat, 1931), which postulates that firm growth is independent from its previous size. In this view, employment growth $G$ of firm $i$ at time $t$ can be written as

$$
G_{i, t}=\epsilon_{t}
$$

where $\epsilon_{i, t}$ is an i.i.d. random variable independent from $i$.

Motivated by the theoretical discussion on the effects of innovation on employment growth - carried on in the previous sections - we enrich the Gibrat's model in the attempt to disentangle the effects associated with product (ProdInn $\left.n_{i, t}\right)$ and process $\left(\operatorname{ProcInn}_{i, t}\right)$ innovation. In particular, as previously emphasized, taking into separate account these kinds of innovative activities is relevant from a theoretical perspective. As a matter of fact, they may be associated with employment growth in a very different way, depending on the extent to which direct effects and different compensation mechanisms work 12

Three main relevant controls are included in the baseline equation: i) lagged employment growth; ii) firm age; iii) affiliation to a business group.

Motivated by the literature that investigates the extent to which growth rates are autocorrelated (see among the others Ijiri and Simon, 1967, Bottazzi and Secchi, 2003, Bottazzi et al., 2007), lagged employment growth allows to take into account dynamic effects in the employment growth process. Recent empirical evidence suggests that young firms disproportionately contribute to net employment growth (see Haltiwanger et al. 2013 and Criscuolo et al., 2014) and motivates including business age as an important

\footnotetext{
${ }^{12}$ This approach does not aim at modeling explicitly the different channels that affect the relationship between different types of innovation and employment. A structural approach has been proposed by Harrison et al. (2014).
} 
control variable. Since firm organizational and corporate structure, and in particular business group affiliation, are notably key drivers of business performance (see among the others Teece, 1996, Mahmood and Mitchell, 2004 and Granovetter, 2005) we also include this variable in our model 13

Controls also include industry and time fixed effects. Industry dummies allow to account for average industry-wide characteristics that might affect employment growth, such as real hourly wage rates, industry-level gross value added (as a proxy for the demand situation in the industry) or sectoral concentration ${ }^{14}$ Year dummies are always included in order to control for common macroeconomic shocks (also considering that the period under analysis includes different phases of the business cycle) 15

The baseline model estimated is therefore

$$
G_{i, t}=\alpha G_{i, t-1}+\beta_{1} \operatorname{ProdInn}_{i, t}+\beta_{2} \operatorname{ProcInn}_{i, t}+\beta_{3} \log \left(\operatorname{age}_{i, t}\right)+\beta_{4} \operatorname{group}_{i, t}+\mu_{i}+v_{i, t}
$$

Recall that $G$ indicates employment growth, as previously defined. In order to simplify the notation, in Equation 3 we do not report time and sector dummies, which are however always included in the estimates; $\mu_{i}$ are firm-specific intercepts, that allow to take into account firm-specific time invariant unobserved heterogeneity, which can lato sensu include managerial abilities (Bloom and Van Reenen, 2010) or organizational routines (see Nelson and Winter, 1982, Dosi, 1988 or Becker, 2004 for a comprehensive review), particularly important in a dynamic capability framework (Teece et al., 1997).

The baseline model is estimated by means of a dynamic Difference-GMM method following Arellano and Bover (1995), which allows to control for unobserved heterogeneity, possible endogeneity of innovation variables and dynamic effects in the employment growth process. All the choices related to the econometric estimation of the model are detailed and motivated in the following subsection.

Further analysis is carried on in a quantile regression framework, aiming at disentangling he role of technical change over the conditional quantiles of the employment growth distribution. This is particularly relevant, especially for policy-makers interested in the effect of innovation on the employment of either fast-growing or shrinking firms, rather than substantially stable (average) ones.

\subsection{Dynamic panel analysis}

Consider the baseline model presented in Equation 3 Estimation by means of ordinary least squares or fixed effects estimations produce inconsistent estimates (Nickell, 1981).

Naive pooled OLS estimation yields inconsistent estimates as $G_{i, t-1}$ is correlated with the firm-specific effect $\mu_{i}$, that would be included in a composite error term $\epsilon_{i, t}$. Furthermore, inconsistency driven by omitted variable bias also may also occur in presence of unobserved firm-specific heterogeneity (such as, in this case, sticky organizational routines or managerial abilities). Fixed effect estimation of the model (by means of the within-group or the LSDV estimators) does not eliminate the dynamic-panel bias. In particular, applying the within-group transformation ${ }^{16}$ the lagged-dependent variable $G *_{i, t-1}$ becomes $G_{i, t-1}-\frac{1}{T-1} \sum_{t=2}^{T} G_{i, t}$, while the idiosyncratic shock $v *_{i, t}$ becomes $v_{i, t}-\frac{1}{T-1} \sum_{t=2}^{T} v_{i, t}$. Fixed effects

\footnotetext{
${ }^{13}$ Note that business group affiliation exhibits a certain degree of variation within firm over time and is not entirely absorbed by the individual fixed effect.

${ }^{14}$ Note however that in a dynamic panel perspective those dummies identify effects associated with changes in the industry, while industry average characteristics are already taken into account by the differencing transformation. In the panel specifications therefore results without industry dummies are also proposed.

${ }^{15}$ This model is consistent with and equivalent to a traditional dynamic employment equation, augmented with innovation variables and a number of controls (as previously described), including lagged employment growth. Our focus is, however, particularly on the employment growth process - and its distribution - rather than on employment levels, therefore we primarily refer to the tradition that proposes stochastic models of firm growth.

${ }^{16}$ Note that the sample restricts to $t=2, \ldots, T$ due to the inclusion of the lagged dependent variable. We denote with a star the elements of the transformed equation.
} 
estimation therefore produces inconsistent estimates because $G *_{i, t-1}$ (in particular its $G_{i, t-1}$ component) correlates with $v *_{i, t}$ (in particular the $\frac{1}{T-1} v_{i, t-1}$ term). Furthermore, $\frac{1}{T-1} G_{i, t-1}$ in $G *_{i, t-1}$ and $v_{i, t}$ in $v *_{i, t}$ are simultaneously determined (see for instance Roodman, 2009a for further discussion).

The estimate of the $\alpha$ coefficient associated with the lagged dependent variable is biased upwards in the case of OLS, while downward biased in the within-group case (see Arellano and Bond, 1991).

Different estimators have been proposed to eliminate the dynamic panel bias. In particular, Arellano and Bond, 1991 propose a transformation of the data that allows removing the dynamic panel bias above described. Namely, they suggest to implement a first-difference transformation. This transformation alone does not eliminate the dynamic panel bias, as $\Delta G_{i, t-1}$ (in particular its component $G_{i, t-1}$ ) is still correlated with $\Delta v_{i, t}$ (in particular its component $v_{i, t-1}$ ). However, longer lags (further back levels of lags) are available as instruments, as orthogonal to the error term. An alternative transformation, which is the one used in this work, is proposed by Arellano and Bover (1995). They suggest to subtract the average of all future available observations. This is attractive because it does not magnify gaps in unbalanced panels, as the first-difference transformation proposed by Arellano and Bond (1991) does. Lagged observations remain valid instruments as they don't enter in the transformation. The choice of a difference GMM method is further driven by the fact that, as suggested in the literature, firm growth rates do not seem to exhibit strikingly high persistence (see for instance Bottazzi et al. 2011), which would limit instruments validity in the GMM difference framework. Furthermore, the validity of additional assumptions required by System GMM (in particular, that changes in the instrumenting variables are not correlated with firm-specific fixed effects) seem at least questionable.

We adopt a two-step estimation strategy, that guarantees robustness to heteroskedasticity patterns ${ }^{17}$ Reported two-step standard error follow the small-sample correction proposed by Windmeijer (2005).

In the baseline specification the innovation variables are considered as predetermined. Building upon the discussion proposed by Lachenmaier and Rottmann (2011), innovation decisions in firms may often be based on long-term considerations because costly and related to organizational change; on the other hand, labor decisions may be taken according to more contingent necessities. In particular, if firms plan their innovative activity at least two periods before the employment decision (because employment growth incorporates employment decisions at time $t$ and $t-1$ ) we can treat the innovation dummies as predetermined (assuming also that companies are not able to anticipate future shocks at the time of the innovation decisions). Validity of this assumptions is hard to establish a priori and will be discussed, in particular looking at the Hansen and Difference-in-Hansen test statistics. Furthermore, this assumption will be relaxed in one of the robustness specifications, which considers innovation as endogenous, reducing therefore the number of valid instruments. Other controls are specified as exogenous. As previously highlighted, estimates with and without industry dummies are proposed in the following.

Estimation of the baseline specification of the model in Table 1 suggests that there is evidence of small but significant autocorrelation in growth rates. The coefficient on the lagged dependent variable highlights that firms that experienced positive employment growth do not repeat it in the subsequent period, but conversely the trend tends to change direction. Furthermore, there is evidence of a positive and significant effect of new-to-the market product innovation in driving employment growth. It particular, estimates suggest that new-to-the-market product innovators grow (in terms of employment) about $1.5 \%$ faster than firms that do not carry on such innovative activity, other covariates held fixed. Finally, process innovation does not seem to have any significant relation with the conditional average of the employment growth distribution.

Commenting on other controls, consistently with corroborated literature (see for instance Haltiwanger et al. 2013 or Criscuolo et al., 2014) young firms tend to exhibit faster employment growth than their

\footnotetext{
${ }^{17}$ Choice of the covariance matrix of the idiosyncratic errors $\mathbf{H}$ for the first-step estimation follows Roodman (2009a).
} 
Table 1: Difference GMM estimates

\begin{tabular}{lcc}
\hline & $(1)$ & $(2)$ \\
\hline$G_{i, t-1}$ & $-0.0519^{* * *}$ & $-0.0505^{* * *}$ \\
& $(0.0188)$ & $(0.0185)$ \\
ProdInn $_{i, t}$ & $0.0149^{* *}$ & $0.0165^{* * *}$ \\
& $(0.00642)$ & $(0.00573)$ \\
ProcInn $_{i, t}$ & 0.00397 & 0.00667 \\
& $(0.00955)$ & $(0.00660)$ \\
log $\left(\right.$ age $\left._{i, t}\right)$ & $-0.0557^{* * *}$ & $-0.0563^{* * *}$ \\
& $(0.0214)$ & $(0.0183)$ \\
group $_{i, t}$ & -0.0121 & $-0.0133^{*}$ \\
& $(0.00797)$ & $(0.00741)$ \\
Industry dummies $_{\text {Year dummies }}$ & YES & $\mathrm{NO}$ \\
& YES & YES \\
\hline Observations & 28,775 & 28,775 \\
Hansen p value & 0.364 & 0.340 \\
AR1 p value & 0 & 0 \\
AR2 p value & 0.433 & 0.384 \\
Number of instruments & 57 & 30 \\
\hline
\end{tabular}

Notes: Robust two-step standard error in parentheses. *** $\mathrm{p}<0.01,{ }^{* *} \mathrm{p}<0.05,{ }^{*} \mathrm{p}<0.1$

older counterparts. Furthermore, affiliation to a business group does not seem to have any effect on changes in employment growth in the sample under scrutiny. Further discussion of the results is carried on in the following.

A key assumption for the validity of the coefficients' estimates proposed is the exogeneity of instruments. When the model is overidentified (as the current case) statistical tests for instrument exogeneity are available ( $J$ test of overidentifying restrictions). A standard specification check for the two-step GMM model estimated is the $J$-test statistic proposed by Hansen (1982). It is a modified version of the older Sargan (1958) test, and is robust to heteroskedasticity.

Focusing on the Hansen p-value, it is evident that it does not reject the null of joint instruments exogeneity. The Hansen test can be also used to check the exogeneity of different subsets of instruments via the Difference-in-Hansen test ( $C$ statistic). The intuition underlying this test statistic exploits estimation of the model with and without a particular set of instruments 18 In this case, we focus on two groups of instruments that refer to i) the lagged dependent variable; ii) the innovation variables. Difference-inHansen p-values (0.138 and 0.2) do not allow to reject the null of instruments validity, and the Hansen p-value remains high when the two groups are separately excluded ${ }^{19}$ The Hansen and Difference-inHansen test are weakened by instruments proliferation (see for instance Bowsher, 2002). The estimates proposed in this paper use collapsed instrument sets to (at least partially) deal with this issue, as suggested by Roodman (2009b) and highlighted in the previous subsection. The instruments count is reported in

\footnotetext{
${ }^{18} \mathrm{An}$ unrestricted model with smaller set of instruments and a restricted one including the instruments for which endogeneity is suspected are compared.

${ }^{19}$ Validity of goodness of the other moments conditions deriving from controls specified as exogenous is also confirmed by looking at other Difference-in-Hansen test statistics.
} 
Table 1

Arellano and Bond (1991) design a test to further check instrument validity. In particular, their test deals with potential autocorrelation of the idiosyncratic error term $\left(v_{i, t}\right)$, which would invalid some instruments. The underlying intuition is that if the idiosyncratic error is serially correlated, part of the instruments would be endogenous (correlated to the error term in differences), and only longer lags would be valid (where the length would depend on the order of autocorrelation found). The Arellano and Bond (1991) test is applied to differenced residuals. ${ }^{20}$ In other words, if $v_{i, t}$ are not serially correlated, differenced residuals would be serially correlated of order 1 by construction, but not of order 2 . We report the p-value for the AR(1) test, which rejects lack of first-order serial correlation, and the p-value for the $\mathrm{AR}(2)$ test, which does not reject lack of second-order serial correlation and therefore does not invalidate (part of) the instruments used.

Weak instrument problems and issues related to instrument strength in the context of dynamic panel GMM models are topics of current discussion (see Bazzi and Clemens, 2013). Stock and Yogo (2005) critical values for first stage $\mathrm{F}$ test (or its multivariate analogue, the Cragg-Donald Wald statistic) are rarely examined in the literature related to this study and - at the best of our knowledge - not implemented as output or options of standard econometrics packages for estimating dynamic panel models, such as xtabond2 (see Roodman, 2009a). Further robustness of these results will be presented in the following.

In order to examine more in depth the role of different product and process innovations, we re-estimate the model presented in Equation 3 splitting the innovation variables into their building components. In this framework, product innovation is split in two dummies, goods and services, and process innovation is split in methods of production, logistics and auxiliary processes, as described in the previous section. At our knowledge, this exercise has not been previously carried on in this stream of literature.

Results presented in Table 2 emphasize that the positive and significant effect of product innovation is confirmed and mainly comes from the introduction of new goods, rather than services. This is particularly meaningful, also given that our study focuses on the manufacturing sector. Furthermore, if anything, auxiliary services appear to have the more labour-friendly role, even if the relevant coefficients are only significant at the $10 \%$ level. The dynamics of other control variables are qualitatively similar to those presented in the main specification. Also in this case, exogeneity and validity of instruments are confirmed by the reported Hansen, AR 1 and AR 2 test statistics, and by unreported Difference-in-Hansen tests.

\subsection{Quantile regression analysis}

Previous analyses focused on the effect of product and process innovation - and their different declinations - on the conditional average of the employment growth distribution, taking into account individual unobserved heterogeneity. However, simplifications associated with the focus on a single moment of the conditional employment growth distribution can hide different effects of the explanatory variables at different points of such distribution. This is particularly relevant, especially for policy-makers interested in the effect of innovation on the employment of either growing or shrinking firms, rather than substantially stable ones.

Quantile regression, firstly introduced by Koenker and Bassett $\operatorname{Jr}(1978)$ has a number of advantages with respect to usual regression methods (see also Coad and Rao 2008 for further discussion). Fist of all, it has been shown that the distribution of the dependent variable is strikingly non-Gaussian. Inference based on assumption of normality of the error terms may not be always appropriate in this case. Furthermore, quantile regression results are characteristically robust to outliers and are able to

\footnotetext{
${ }^{20}$ Even if the estimation is carried on in orthogonal deviations. The test assumes that no regressor is post-determined and that errors are not correlated across individuals (see Roodman, $2009 \mathrm{~b}$ for further details).
} 
Table 2: Difference GMM estimates - Spliting innovation variables

\begin{tabular}{|c|c|c|}
\hline & (1) & $(2)$ \\
\hline$G_{i, t-1}$ & $\begin{array}{c}-0.0528^{* * *} \\
(0.0178)\end{array}$ & $\begin{array}{c}-0.0488^{* * *} \\
(0.0173)\end{array}$ \\
\hline $\operatorname{ProdInn}_{i, t}($ goods $)$ & $\begin{array}{l}0.0137^{* *} \\
(0.00657)\end{array}$ & $\begin{array}{c}0.0177^{* * *} \\
(0.00588)\end{array}$ \\
\hline $\operatorname{ProdInn}_{i, t}($ services $)$ & $\begin{array}{l}-0.000347 \\
(0.00731)\end{array}$ & $\begin{array}{l}-0.00213 \\
(0.00720)\end{array}$ \\
\hline $\operatorname{ProcInn}_{i, t}$ (methods) & $\begin{array}{l}-0.00329 \\
(0.00713)\end{array}$ & $\begin{array}{c}0.00146 \\
(0.00557)\end{array}$ \\
\hline ProcInn $_{i, t}$ (logistics) & $\begin{array}{c}0.00694 \\
(0.00743)\end{array}$ & $\begin{array}{c}0.00653 \\
(0.00733)\end{array}$ \\
\hline ProcInn $_{i, t}$ (auxiliary) & $\begin{array}{c}0.0102^{*} \\
(0.00593)\end{array}$ & $\begin{array}{c}0.0102^{*} \\
(0.00530)\end{array}$ \\
\hline $\log \left(a g e_{i, t}\right)$ & $\begin{array}{c}-0.0559^{* * *} \\
(0.0213)\end{array}$ & $\begin{array}{c}-0.0563^{* * *} \\
(0.0181)\end{array}$ \\
\hline group $_{i, t}$ & $\begin{array}{c}-0.0121 \\
(0.00767)\end{array}$ & $\begin{array}{c}-0.0133^{*} \\
(0.00733)\end{array}$ \\
\hline Industry dummies & YES & $\mathrm{NO}$ \\
\hline Year dummies & YES & YES \\
\hline Observations & 28,775 & 28,775 \\
\hline Hansen $\mathrm{p}$ value & 0.685 & 0.578 \\
\hline AR1 p value & 0 & 0 \\
\hline AR2 p value & 0.504 & 0.367 \\
\hline Number of instruments & 81 & 54 \\
\hline
\end{tabular}

Notes: Robust two-step standard error in parentheses. *** $\mathrm{p}<0.01, * * \mathrm{p}<0.05, * \mathrm{p}<0.1$

picture the effect of covariates on the entire conditional distribution of employment growth. However, quantile regression estimates proposed do not control for potential unobserved heterogeneity ${ }^{21}$ Comparing previously presented GMM estimates with simple pooled OLS can be informative on the direction of the bias. As presented in the Appendix (see Table A5, the product innovation coefficient is estimated quite accurately by a simple OLS, while the process innovation one is overestimated. As expected, the lagged dependent variable coefficient is instead biased upwards. This caveats shall be taken in mind when analysing the following sets of robust correlations, which do not pretend to draw any causal claim.

In this subsection the results of the estimation of Equation 3 by means of quantile regression are presented ${ }^{22}$ The following figures graph the coefficients associated with innovation covariates over the

\footnotetext{
${ }^{21}$ This means that, referring to Equation 3, we do not separate $\mu_{i}$ from $v_{i, t}$. Despite a growing literature on fixed effects quantile regression is growing, at our knowledge there is still little consensus on the topic especially in presence of models - like ours - that include a lagged dependent variable. A simple approach to quantile regression for panel data has been proposed by Canay (2011), but the limited length of the panel at our disposal (small $t$ ) prevents us from consistently applying it.

${ }^{22}$ Graphs that describe the effect of the innovation covariates on the whole conditional distribution of the response variable are reported in the main body, while estimates at 5 points of the conditional distribution of the dependent variable (namely, the 15th, 30th, 50th, 70th and 85th percentiles) are reported in the Appendix (Table A6 and A7). Conditional quantiles are estimated separately. Robust and clustered standard errors are reported in parentheses in the tables, following Parente and
} 
whole conditional distribution of employment growth (from the 10th to the 90th percentiles). Graphs from the baseline specification are reported in Figure 4a (new-to-the-market product innovation dummy) and 4b (process innovation dummy). Graphs from the second specification (splitting innovation variables) are \begin{tabular}{|l|l|l|l|l|}
\hline reported in Figure $5 \mathrm{a}$ & (the new-to-the-market goods dummy); in Figure $5 \mathrm{~b}$ (new-to-the-market services \\
\hline
\end{tabular} dummy); in Figure 6a (new methods); 6b (new logistics systems); 6c (new auxiliary processes).

Figure 4: Quantile regression coefficients - Main innovation variables

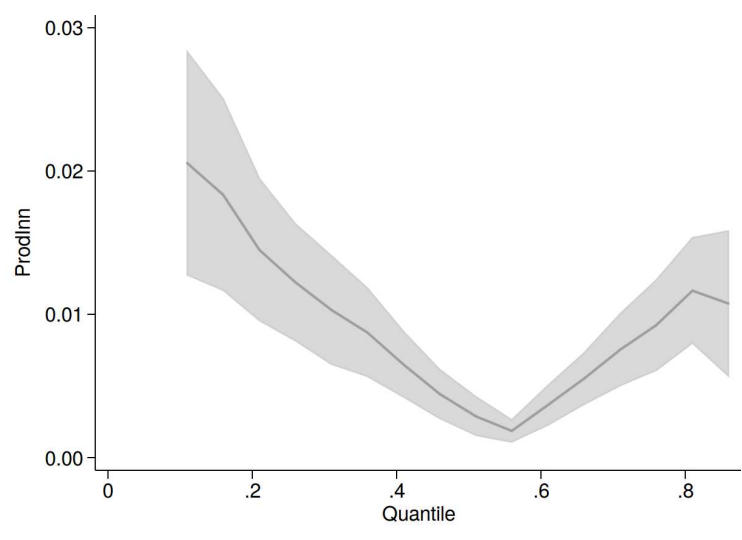

(a) Product Innovation

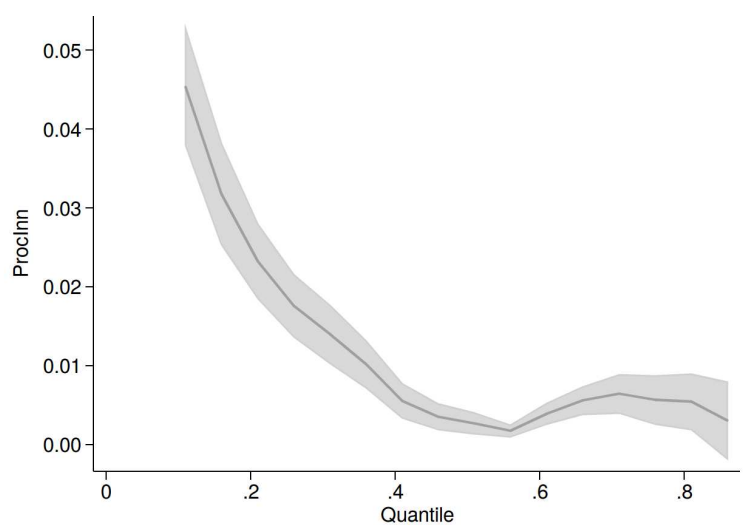

(b) Process innovation

Notes: Quantile regression coefficients associated with new-to-the-market product innovation (on the left) and process innovation (on the right) from Equation 3. The shaded area represents a 95\% confidence band, calculated according to Koenker and Bassett Jr (1982).

Figure 5: Quantile regression coefficients - Splitting product innovation

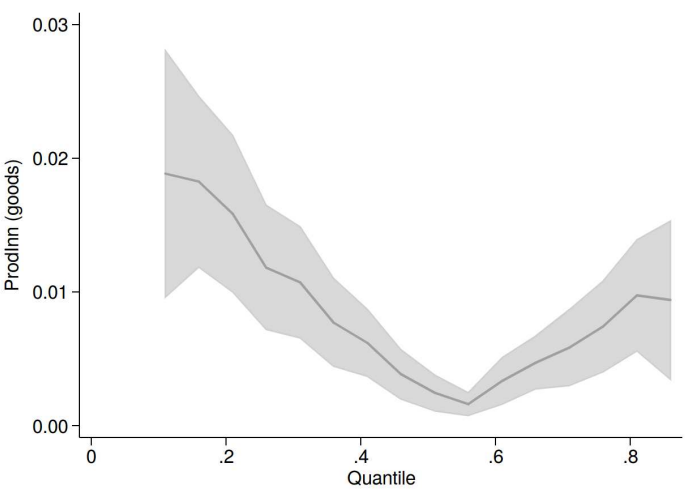

(a) Product Innovation - Goods

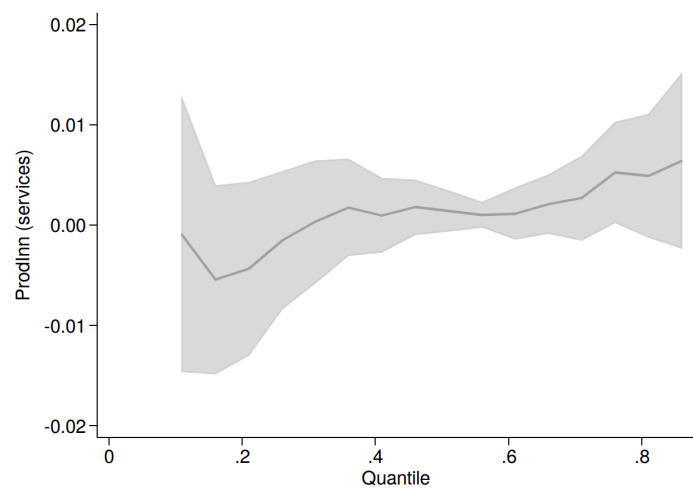

(b) Product Innovation - Services

Notes: Quantile regression coefficients associated with new-to-the-market product innovation - goods (on the left) and services (on the right) from Equation 3 The shaded area represents a 95\% confidence band, calculated according to Koenker and Bassett Jr (1982). 
Figure 6: Quantile regression coefficients - Splitting process innovation

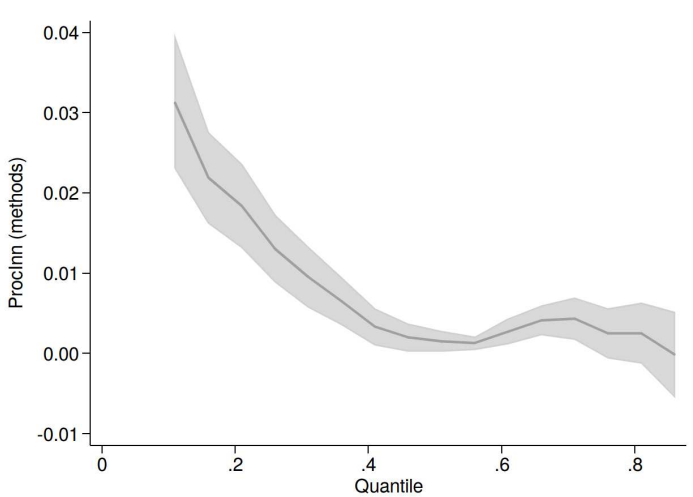

(a) Process Innovation - Methods

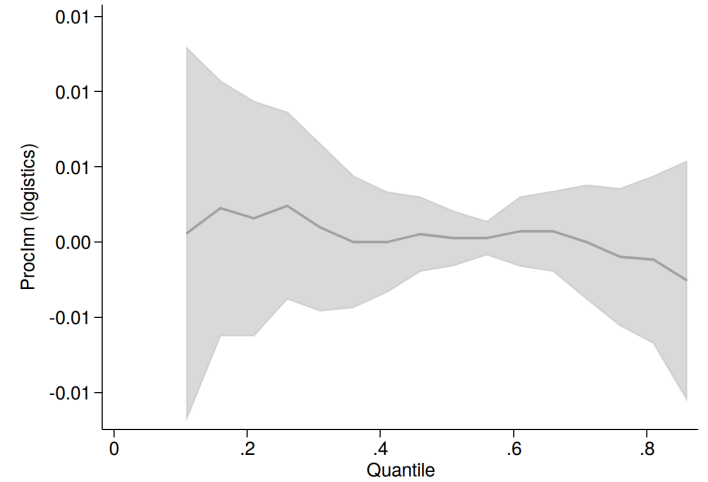

(b) Process Innovation - Logistics

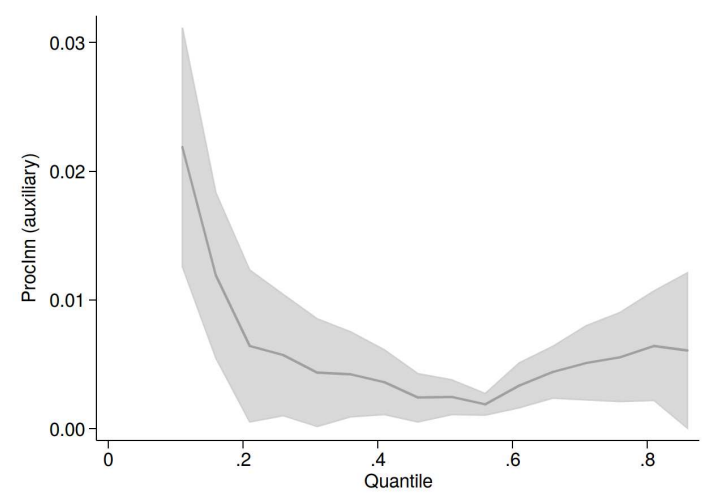

(c) Process Innovation - Auxiliary Processes

Notes: Quantile regression coefficients associated with process innovation - methods (on the top left); logistics (on the top right) and auxiliary processes (on the bottom) from Equation 3 The shaded area represents a 95\% confidence band, calculated according to Koenker and Bassett Jr (1982).

Let us focus on the first specification presented in Figure 4 (and Table A6), where only two innovation dummies are included. New-to-the-market product innovation appears positively and significantly associated with employment growth over the entire conditional employment growth distribution. The magnitude of the effect exhibits a U-shaped pattern, higher at the bottom of the conditional distribution and, to a lower extent, between the 60th and 85th percentile. Process innovation, instead, looks more positively associated with employment growth at the bottom of its conditional distribution. The magnitude of such effect is decreasing in the conditional quantiles. In the top of the distribution, in fact, process innovation does not seem to be a significant determinant of employment growth (looking at the confidence bands note that we cannot reject a coefficient with negative sign at the very top of the distribution).

Separately looking at the different building blocks of product and process innovation (see also Table A7 allows disentangling different contributions to the otherwise net effect of innovation on employment growth, presented in the main specification. Focusing on goods and services new to the entire market, one can notice that the effect of goods is similar to the general pattern of product innovation, while the effect of services is more evidently increasing in the conditional quantiles (despite generally not statistically significant). Furthermore, de-constructing the general effect of process innovation by means of different 
dummies, one can notice that it is mainly driven by new methods, which are the main component of process innovation. Conversely, despite less frequent in the database, auxiliary processes confirm to have a positive and significant effect across all the conditional employment growth distribution.

Other covariates exhibit a similar pattern, both in the first and second specification. Lagged age has a positive effect in the bottom of the conditional growth distribution (suggesting lower degrees of adjustment of employment for older and larger highly shrinking firms). Its effect turns negative in the rest of the distribution suggesting, as previously mentioned, violation of the Gibrat's law for younger firms, which tend to grow faster. Business group affiliation has a positive effect on employment growth in the bottom of the distribution and a negative effect on the top. This suggests a dual effect of business group affiliation, providing institutional infrastructure to shrinking firms but possibly hindering the proliferation of radical innovations in faster growing firms. The magnitude of the lagged dependent variable coefficient remains overall small, further highlighting a limited degree of autocorrelation of employment growth rates. Goodness of fit of the regressions (calculated via pseudo R-squared) is low but comparable with other studies in the literature, and not particularly meaningful in a quantile regression setting.

\section{Robustness}

A number of further exercises have been carried on in order to extend and test the robustness of the above presented findings. They are reported in the following subsections and include: i) using a different employment growth measure; ii) using a different product innovation measure; iii) assessing the complementarities of innovation strategies; iv) specifying the group variable as predetermined; v) specifying the innovation variables as endogenous; vi) using lagged innovation variables to deal with simultaneity in quantile regression 23

\subsection{Different employment growth measure}

Firstly, a replication of all estimates using a different definition of employment growth $\left(g_{i, t}\right)$ is presented in Appendix (Table A8, A9 and A10.

Following the job flows literature (see for instance Davis and Haltiwanger, 1999), $g_{i, t}$ is defined as follows:

$$
g_{i, t}=\frac{E_{i, t}-E_{i, t-1}}{0.5 \times\left(E_{i, t}+E_{i, t-1}\right)} .
$$

This measure ranges between -2 and 2 , portraits employment contraction and expansion symmetrically, allowing for an integrated treatment of entry and exit, and is monotonically related to the conventional growth rate measure. It also shares useful properties in terms of log differences and can be flexibly defined for different levels of aggregation (see Davis and Haltiwanger, 1999 or Haltiwanger et al., 2013 for further details).

Both GMM and quantile regression results are in line with the ones previously discussed. The coefficient related to auxiliary processes becomes significant at the 5\% level in the GMM specification in Column 4 of Table A8, further pointing to the positive role of such type of innovative activities.

\footnotetext{
${ }^{23}$ Further unreported robustness have also excluded potential outliers, included further lags of innovation variables (up to the second) and restricted the number of lags used as valid instruments in the main GMM model, without affecting the main conclusions.
} 


\subsection{Different product innovation measure}

Secondly, we test the robustness of the results using a different innovation variable for product innovation. In Table A11 and A12 in Appendix we present the estimates of Equation 3replacing the product innovation dummy with a continuous measure that identifies the (log) turnover spent for new-to-the-market product innovations. This measure is unfortunately not available for process innovation (as in most innovation surveys) 24

Also this specification corroborates the results previously presented, with no variation in the sign and significance of the relevant coefficients in both the GMM and the quantile regression estimates.

\subsection{Complementarity of Innovation Strategies}

We further extend the previous findings by estimating Equation 3 with a different set of dummies, in order to take into preliminary account the complementarities existing between product and process innovation strategies. In Table A13 and A14, instead of the ProdInn and ProcInn dummies, we use three different variables, which are defined as follows 25

1. ProdInn only: dummy equal to 1 if the firm introduces new or significantly improved products and does not introduce any new or significantly improved process; zero otherwise;

2. ProcInn only: dummy equal to 1 if the firm introduces new or significantly improved processes and does not introduce any new or significantly improved product; zero otherwise;

3. ProdInn only \& ProcInn only: dummy equal to 1 if the firm introduces both new or significantly improved products and processes; zero otherwise.

This classification of innovative activities allows to further separate specificities associated with product and process innovation alone when examining their correlation with employment growth.

Table A13 presents the estimates on the conditional average of the employment growth distribution. The results confirm the positive role of product innovation. The coefficient of ProdInn only is in fact positive and significant, with magnitude approximately two times higher than the coefficient presented in Table 1. ProcInn only remains instead not significant at 5\% level. Coefficients of combined product and process innovation are positive and significant only in one of the two specifications. Other variables remain stable.

Qualitative patterns of estimates presented in Table A14 corroborate the main findings, with a Ushaped effect of product innovation only, and positive effect of process innovation only especially at the bottom of the conditional growth distribution.

\subsection{GMM: predetermined group variable}

We also re-estimate all the GMM models specifying the group variable as predetermined. Results are presented in Table A15. The sign, magnitude and significance of the coefficients are qualitatively very similar to the results presented in the main body of text. The group coefficient is never significantly significant, confirming that affiliation to a business group does not seem to have any effect on changes in employment growth in the sample under scrutiny. In one of the specifications (with industry dummies), the product innovation coefficient is significant only at the $10 \%$ level.

\footnotetext{
${ }^{24}$ It is not possible to separate the share of turnover dedicated to new goods and services.

${ }^{25}$ We keep referring to product innovations new to the entire market, as in the rest of the paper.
} 


\subsection{GMM: endogenous innovation variables}

In order to further test our results, we estimate the main GMM model (as presented in Table 1 and in Table A15 specifying all innovation variables as endogenous. Estimates are reported in Table A16 for reference. The sign of the coefficients tends to be generally stable, despite in some cases they are estimated less precisely.

Since in the models that treat innovation variables as endogenous the set of moment conditions is a strict subset of the moment conditions in the models where innovation variables are predetermined, we can use Difference-in-Hansen tests to assess the validity of the additional instruments in the models with predetermined innovation.

This tests show that the models treating innovations as predetermined is not rejected ${ }^{26}$ This further corroborates our choice to treat innovation variables as predetermined.

\subsection{Quantile regression: lagged innovation variables}

As previously mentioned, the quantile regression setting does not allow to take into proper account endogeneity issues. However, we have tried a number of different specifications that corroborate the results presented in the analysis.

In addition to the previously presented robustness, Table A17 and A18 show the coefficient estimates resulting from replacing innovation variables with their first lag, in order to partially deal with simultaneity issues. The results presented in Table A17 are substantially in line with those presented in Table A6. When splitting the innovation dummies in their building blocks in Table A18, estimates confirm the positive role of new goods across the whole distribution and of new methods at the bottom of the conditional distribution. Few differences are also evident. The change of sign in the methods coefficients at the top of the distribution is now statistically significant, confirming that the effect of this type of innovation decreases in the conditional quantiles. The positive role of auxiliary processes remains statistically significant only at the bottom of the conditional distribution.

\section{Discussion}

In this section, further discussion of the main findings and their limitations is presented. This study suggests that product innovation is associated with higher average employment growth, other covariates held fixed. It particular, estimates suggest that new-to-the-market product innovators grow (in terms of employment) about $1.5 \%$ faster than firms that do not carry on such innovative activity, other covariates held fixed. This is consistent with a good number of studies that investigate such relation at the firm level (including Harrison et al., 2014, Evangelista and Vezzani, 2012, Crespi and Tacsir, 2012, Hall et al., 2009 and Benavente and Lauterbach, 2008).

The role of process innovation is instead more ambiguous. Effects on the conditional average of the employment growth distribution are not statistically different from zero. Differently from what found by Lachenmaier and Rottmann (2011) and Triguero et al. (2014), this suggests that compensation mechanisms tend to act in opposite directions and on average result in a zero net effect.

Digging more in depth into the building blocks of innovative activities has been promising, confirming their high degree of complexity. A focus on the effects on the conditional average of the employment growth distribution suggests that introducing new or significantly improved goods, and to a lesser extent auxiliary processes seem particularly associated with higher employment growth.

\footnotetext{
${ }^{26}$ Unreported tests on the model that splits innovation variables in their building blocks provide analogous insights. The p-values of the tests are always larger than 0.34 .
} 
Quantile regression has been particularly useful to study the relationship between different types of innovation and employment growth. Firstly, it allows examining the impact of different kinds of innovations along the whole employment growth distribution. Especially from a policy perspective, focusing on the effect of innovation on (high-growth) firms on the top of the conditional distribution of employment growth is particularly relevant. Secondly, it allows overcoming the limitations associated with non-normality of the distribution of the response variable and is particularly robust to outliers. Thirdly, as further detailed in the following, it might help reconciling the ambiguous effects of process innovation which have been documented in the literature.

The effect of product innovation is significantly positive over the whole conditional employment growth distribution, and its magnitude is somehow U-shaped. Introduction of new goods seems particularly associated with employment growth at the bottom of the distribution and, to a lesser extent, between the 60 th and the 85 th percentile. Introduction of new services seems, instead, not significantly associated with employment growth, despite de magnitude of the coefficient grows in the conditional quantiles.

The interpretation of the variation in magnitude of the effects associated with the introduction of new goods over the conditional employment growth distribution might not be completely intuitive. One could expect the effect of innovation on employment growth for firms at the top of the conditional distribution to be higher in magnitude than elsewhere 27 Despite finding a positive effect, our analysis does not highlight a disproportionately high magnitude when focusing on the top of the distribution (this is consistent with the analysis of Zimmermann, 2009 on German SMEs). One of the possible explanations is linked to the extent to which high-growth firms in the Spanish manufacturing sectors cannibalize their old products with new ones. An example could come from companies in the Spanish fashion cluster ${ }^{28}$. Traditionally, this cluster has been characterized by high innovativeness but also almost complete replacement of old products with constantly new ones. This might suggest that the extent to which new products cannibalize older ones might likely vary over the conditional employment growth distribution. Furthermore, this pattern could also reflect country specificities and the peculiarity of the time period considered (which includes most of the recession years, in which higher demand associated with product innovation could have been constrained).

The (net) effect of process innovation, especially of new methods of production, is decreasing in the quantiles of the conditional employment growth distribution, more significantly positive at the bottom of the distribution. This is at odds with the analysis on Norwegian data by Herstad and Sandven (2015) but consistent with the study on the sales distribution of Spanish manufacturing firm by Bianchini et al. (2016). One of the ways to possibly reconcile the magnitude of such effect could be to link it with the extent to which the price compensation mechanism works at different point of the conditional employment growth distribution. Recall that such mechanism suggests that the price decrease associated with process innovation boosts demand, (over) compensating the reduction of workforce due to productivity improvements. The extent to which the price mechanism effectively works depends on the market power of firms and on the market structure. Young firms are expected to have lower market power and therefore to be less able to effectively reduce prices. For this category of businesses, the effect of process innovation may tend to be closer to the theoretically predicted negative one, linked to higher efficiency rather than output increase. Those firms might well be the ones that, however, are mostly located at the top of the employment growth distribution. In our database, this tends to be supported also looking at the negative sign of the age coefficients above the median of the distribution (substantially negative towards the top), which suggests that especially younger firms are associated with higher employment growth (see also Criscuolo et al., 2014). Despite such interpretation is speculative and deserves further investigation, these

${ }^{27}$ See for instance Coad and Rao (2011) using a different innovation proxy on high-tech sectors in the United States.

${ }^{28}$ Where a large number of brands and networks of suppliers are involved. 
dynamics would be hidden in a framework that does not look comprehensively at the effects of innovation on the whole employment growth distribution.

Finally and interestingly, auxiliary processes exhibit a significantly positive trend across the whole conditional employment growth distribution. This result is interesting in the light of the debate on the effects of digitalization (which is at the root of a good part of such activities) on employment growth and firm performance (see for instance Brynjolfsson and Hitt, 2000).

\subsection{Limitations}

Each of the empirical estimates carried on relies on different assumptions and has particular intrinsic limitations, which have been discussed throughout this essay. We believe that a combination of different empirical methods is a valuable approach, in the attempt to have a comprehensive overview of the relationship between innovation and employment growth in the sample.

No external validity is claimed. Results are therefore limited to the specific time period under consideration in the Spanish manufacturing sector, as represented by the database used. In this respect, both Harrison et al. (2014) and Hölzl (2009) suggest that the extent to which results based on Spanish data are generalizable to other countries (such as France, Germany or the UK for instance) is somehow limited. Further analysis should therefore corroborate the estimates using different databases in other countries.

Limited discussion has been carried on about the persistence of innovative activities. A valuable approach using Spanish data is proposed by Triguero et al. (2014). Further investigation on this topic - which could be particularly challenging in a panel data framework - seems a promising avenue of further research. No analysis has been conduced to look at the extent to which different innovative activities influence simultaneously the employment and sales growth processes. This also seems a fruitful avenue for further investigation, which has clear linkages with the literature that assesses the link between innovation and productivity (see Mohnen and Hall, 2013 for a recent survey).

Furthermore, the main focus of the analysis has been on manufacturing firms that populate the PITEC database. As shown in the descriptive statistics, most of these firms are continuing incumbents. Much of the role of entry and exit is therefore left for future research (see also Harrison et al. 2014 for further discussion). Further analysis of sectoral specificities and on the role of non-technological innovation are also left for further research.

The framework of analysis, due to data limitations, does not take into account effects of innovation on the composition of employment (see for instance Giuliodori and Stucchi, 2012 for an analysis on Spanish data) nor on the degree of persistence of the jobs created (Ciriaci et al. 2015 provide indirect evidence on this issue using the same database).

Let us highlight, once again, that the analysis is carried on at firm level. As previously mentioned, no direct conclusion on the effect of innovation on employment growth at more aggregate level would be appropriate. As a matter of fact, selection, business stealing and market expansion effects, firm entry and exit, relocation of activities, may induce completely different dynamics at higher levels of aggregation. Firm-level studies should therefore be adequately complemented by sectoral and macro analyses. However, a credible comparison between micro and aggregate data requires highly representative database, such as Business Register records matched with innovation data.

A final note of caution is provided, remarking that CIS-like databases (including PITEC), suffer from a number of limitations associated with self-reporting, measurement errors, representativeness of the sample (which has been discussed in Appendix) and anonymization challenges. However, we believe they are still able to offer a good (and unique) first degree of approximation concerning firm-level innovation activities and dynamics (see Mairesse and Mohnen, 2010 for further discussion). 


\section{Conclusions}

This work has studied the firm-level relationship between different types of innovative activities and employment growth rates. Improving on previous investigations on the topic - which mainly focus on the effect of a limited number of innovation indicators on the conditional average of the employment growth distribution - this essay has combined a dynamic panel analysis of the effects of different types of product and process innovation on employment growth with an outlook on the whole conditional employment growth distribution. Departing from conditional averages has allowed to focus on the role of innovation driving employment growth of fast-growing or shrinking firms, rather than substantially stable (average) ones, which is particularly important from a policy perspective.

The analysis has been carried on using a panel of Spanish firms in the manufacturing sector from 2004 to 2012 (Panel Innovación Tecnológica). It has combined descriptive non-parametric analysis with different econometric techniques. Namely, a dynamic panel GMM framework - that has allowed to control for unobserved heterogeneity, possible endogeneity of innovation variables and dynamic effects in the employment growth process - has been combined with a quantile regression analysis, aimed at disentangling the role of technical change over the conditional employment growth distribution.

The results have shown that product innovation - especially goods, when new to the entire market has a positive effect influencing employment growth. This role is likely to be particularly relevant for both fast-growing and shrinking firms. Process innovation appears instead to have less clear-cut effects, which are likely to result from different compensation mechanisms acting in opposite directions, consistently with existing evidence. Among different types of process innovation, the introduction of novel auxiliary processes appears to be more positively linked with employment growth.

\section{References}

Arellano, M. And S. Bond (1991): "Some tests of specification for panel data: Monte Carlo evidence and an application to employment equations," The Review of Economic Studies, 58, 277-297.

Arellano, M. And O. Bover (1995): "Another look at the instrumental variable estimation of errorcomponents models," Journal of Econometrics, 68, 29-51.

Autor, D., F. Levy, And R. Murnane (2003): "The skill content of recent technological change: An empirical exploration," The Quarterly Journal of Economics, 118, 1279-1333.

Barba Navaretti, G., D. Castellani, and F. Pieri (2014): "Age and firm growth: evidence from three European countries," Small Business Economics, 43, 823-837.

Bazzi, S. And M. A. Clemens (2013): "Blunt instruments: avoiding common pitfalls in identifying the causes of economic growth," American Economic Journal: Macroeconomics, 5, 152-186.

BeCker, M. C. (2004): "Organizational routines: a review of the literature," Industrial and Corporate Change, 13, 643-678.

Benavente, J. M. and R. Lauterbach (2008): "Technological innovation and employment: complements or substitutes?" The European Journal of Development Research, 20, 318-329.

Bianchini, S., G. Pellegrino, and F. Tamagni (2016): "Innovation strategies and firm growth," LEM Working Paper Series 2016/03, Scuola Superiore Sant'Anna. 
Bloom, N. And J. VAn ReEnen (2010): "Why do management practices differ across firms and countries?" The Journal of Economic Perspectives, 24, 203-224.

Bottazzi, G., E. Cefis, G. , And A. Secchi (2007): "Invariances and diversities in the patterns of industrial evolution: Some evidence from Italian manufacturing industries," Small Business Economics, $29,137-159$.

Bottazzi, G., A. Coad, N. Jacoby, And A. Secchi (2011): "Corporate growth and industrial dynamics: Evidence from French manufacturing," Applied Economics, 43, 103-116.

Bottazzi, G. And A. SeCchi (2003): "Common properties and sectoral specificities in the dynamics of US manufacturing companies," Review of Industrial Organization, 23, 217-232.

- (2006): "Explaining the distribution of firm growth rates," The RAND Journal of Economics, 37, $235-256$.

Bowsher, C. G. (2002): "On testing overidentifying restrictions in dynamic panel data models," Economics letters, $77,211-220$.

Brynjolfsson, E. And L. M. Hitt (2000): "Beyond computation: Information technology, organizational transformation and business performance," The Journal of Economic Perspectives, 14, 23-48.

Calvino, F. And M. E. Virgillito (2016): "The innovation-employment nexus: a critical survey of theory and empirics," LEM Working Paper Series No. 2016/10, Scuola Superiore Sant'Anna.

CAnAy, I. A. (2011): "A simple approach to quantile regression for panel data," The Econometrics Journal, 14, 368-386.

Ciriaci, D., P. Moncada-Paternò-Castello, and P. Voigt (2015): "Innovation and job creation: a sustainable relation?" Eurasian Business Review, 1-25.

CoAD, A. (2010): "The exponential age distribution and the Pareto firm size distribution," Journal of Industry, Competition and Trade, 10, 389-395.

COAD, A. AND R. RAO (2008): "Innovation and firm growth in high-tech sectors: A quantile regression approach," Research Policy, 37, 633-648.

(2011): "The firm-level employment effects of innovations in high-tech US manufacturing industries," Journal of Evolutionary Economics, 21, 255-283.

Coad, A., A. Segarra, And M. Teruel (2016): "Innovation and firm growth: Does firm age play a role?" Research Policy, 45, 387-400.

Crespi, G. And E. TACsir (2012): "Effects of innovation on employment in Latin America," IDB Technical Note No. 496, Inter-American Development Bank.

Crisculolo, C., P. N. Gal, and C. Menon (2014): "The Dynamics of Employment Growth," OECD Science, Technology and Industry Policy Papers No. 14, OECD Publishing, Paris.

Davis, S. J. And J. Haltiwanger (1999): "Gross job flows," in Handbook of Labor Economics, ed. by D. Card and O. Ashenfelter, Amsterdam: North-Holland, vol. 3, 2711-2805. 
Dosi, G. (1984): "Technology and conditions of macroeconomic development," in Design, Innovation and Long Cycles in Economic Development, ed. by C. Freeman, London: Design Research Publications, 99125.

(1988): "Sources, procedures, and microeconomic effects of innovation," Journal of Economic Literature, 26, 1120-1171.

Evangelista, R. And A. VezZANi (2012): "The impact of technological and organizational innovations on employment in European firms," Industrial and Corporate Change, 21, 871-899.

FALK, M. (2012): "Quantile estimates of the impact of R\&D intensity on firm performance," Small Business Economics, 39, 19-37.

Gibrat, R. (1931): Les inégalités économiques, Paris: Recueil Sirey.

Giuliodori, D. AND R. Stucchi (2012): "Innovation and job creation in a dual labor market: evidence from Spain," Economics of Innovation and New Technology, 21, 801-813.

Granovetter, M. (2005): Business Groups and Social Organization, Princeton University Press, chap. 19, 429.

Greenan, N. And D. Guellec (2000): "Technological innovation and employment reallocation," Labour, 14, 547-590.

Hall, B. H., F. Lotti, And J. Mairesse (2009): "Innovation and productivity in SMEs: empirical evidence for Italy," Small Business Economics, 33, 13-33.

Haltiwanger, J., R. S. Jarmin, And J. Miranda (2013): "Who creates jobs? Small versus large versus young," Review of Economics and Statistics, 95, 347-361.

Hansen, L. P. (1982): "Large sample properties of generalized method of moments estimators," Econometrica: Journal of the Econometric Society, 50, 1029-1054.

Harrison, R., J. Jaumandreu, J. Mairesse, And B. Peters (2014): "Does innovation stimulate employment? A firm-level analysis using comparable micro-data from four European countries," International Journal of Industrial Organization, 35, 29-43.

Herstad, S. J. And T. SAndven (2015): "Innovation and corporate employment growth revisited," Papers in Innovation Studies No. 2015/3, Lund University, CIRCLE-Center for Innovation, Research and Competences in the Learning Economy.

HöLzL, W. (2009): "Is the R\&D behaviour of fast-growing SMEs different? Evidence from CIS III data for 16 countries," Small Business Economics, 33, 59-75.

IJIRI, Y. AND H. A. Simon (1967): "A model of business firm growth," Econometrica: Journal of the Econometric Society, 35, 348-355.

Keynes, J. M. (1931): "Economic possibilities for our grandchildren," in Essays in persuasion, London: Macmillan \& Co., 358-73.

Koenker, R. And G. Bassett JR (1978): "Regression quantiles," Econometrica: journal of the Econometric Society, 46, 33-50. 
(1982): "Robust tests for heteroscedasticity based on regression quantiles," Econometrica: Journal of the Econometric Society, 50, 43-61.

Lachenmaier, S. and H. Rottmann (2007): "Employment effects of innovation at the firm level," Jahrbücher für Nationalökonomie und Statistik, 227, 254-272.

(2011): "Effects of innovation on employment: A dynamic panel analysis," International Journal of Industrial Organization, 29, 210-220.

LóPEZ, A. (2011): "The effect of microaggregation on regression results: an application to Spanish innovation data," MPRA Paper.

Mahmood, I. P. And W. Mitchell (2004): "Two faces: Effects of business groups on innovation in emerging economies," Management Science, 50, 1348-1365.

Mairesse, J. And P. Mohnen (2010): "Using innovation surveys for econometric analysis," in Handbook of the Economics of Innovation, ed. by B. H. Hall and N. Rosenberg, Amsterdam: North-Holland, vol. 2, $1129-1155$.

Michaels, G. and G. Graetz (2015): "Robots at Work," CEP Discussion Paper No.1335, Centre for Economic Performance.

Mohnen, P. And B. H. Hall (2013): "Innovation and productivity: an update," Eurasian Business Review, 3, 47-65.

Nelson, R. R. And S. G. Winter (1982): An evolutionary theory of economic change, Cambridge, MA: Harvard University Press.

Nickell, S. (1981): "Biases in dynamic models with fixed effects," Econometrica: Journal of the Econometric Society, 49, 1417-1426.

OECD And Eurostat (2005): Oslo Manual: Guidelines for Collecting and Interpreting Innovation Data, 3rd Edition, The Measurement of Scientific and Technological Activities, OECD Publishing.

Parente, P. And J. Santos Silva (2016): "Quantile Regression with Clustered Data," Journal of Econometric Methods, 5, 1-15.

Peters, B., B. Dachs, M. Dünser, M. Hud, C. Köhler, and C. Rammer (2014): Firm Growth, Innovation and the Business Cycle, No. 110577, Mannheim: ZEW - Center for European Economic Research.

Pianta, M. (2005): "Innovation and employment," in The Oxford Handbook of Innovation, ed. by D. M. J. Fagerberg and R. Nelson, Oxford: Oxford University Press, 568-598.

Ricardo, D. (1817): On the principles of political economy and taxation, London: John Murray.

Roodman, D. (2009a): "How to do xtabond2: An introduction to difference and system GMM in Stata," Stata Journal, 9, 86-136.

- (2009b): "A note on the theme of too many instruments," Oxford Bulletin of Economics and Statistics, 71, 135-158. 
SARgan, J. D. (1958): "The estimation of economic relationships using instrumental variables," Econometrica: Journal of the Econometric Society, 26, 393-415.

Schmid, M. And H. Schneeweiss (2009): "The effect of microaggregation by individual ranking on the estimation of moments," Journal of Econometrics, 153, 174-182.

Segarra, A. and M. Teruel (2014): "High-growth firms and innovation: an empirical analysis for Spanish firms," Small Business Economics, 43, 1-17.

Simonetti, R., K. Taylor, and M. Vivarelli (2000): "Modelling the Employment Impact of Innovation," in The Employment Impact of Innovation: Evidence and Policy, ed. by M. Vivarelli and M. Pianta, London: Routledge, 26-43.

Spiezia, V. And M. Vivarelli (2002): "Innovation and employment: A critical survey," in Productivity, Inequality and the Digital Economy: A Transatlantic Perspective, ed. by N. Greenan, L. Y., and J. Mairesse, Cambridge, MA: MIT Press, 101-31.

Stock, J. H. AND M. Yogo (2005): "Testing for weak instruments in linear IV regression," Identification and inference for econometric models: Essays in honor of Thomas Rothenberg.

TeEce, D. J. (1996): "Firm organization, industrial structure, and technological innovation," Journal of Economic Behavior \& Organization, 31, 193-224.

Teece, D. J., G. Pisano, and A. Shuen (1997): "Dynamic capabilities and strategic management," Strategic Management Journal, 18, 509-533.

Triguero, A., D. Corcoles, And M. C. Cuerva (2014): "Persistence of innovation and firms growth: evidence from a panel of SME and large Spanish manufacturing firms," Small Business Economics, 43, $787-804$.

VivarelLi, M. (1995): The economics of technology and employment: theory and empirical evidence, London: Edward Elgar Publishing.

(2014): "Innovation, Employment and Skills in Advanced and Developing Countries: A Survey of Economic Literature," Journal of Economic Issues, 48, 123-154.

WindmeijeR, F. (2005): "A finite sample correction for the variance of linear efficient two-step GMM estimators," Journal of Econometrics, 126, 25-51.

Zimmermann, V. (2009): "The impact of innovation on employment in small and medium enterprises with different growth rates," Jahrbücher für Nationalökonomie und Statistik, 229, 313-326. 


\section{Appendix}

\section{Panel composition}

Details on the composition of the panel are reported in Table A1. Note that the number of observations used for estimation reduces due to the inclusion of the lagged dependent variable and to missing patterns in the age variable described in the following.

Table A1: Composition of the panel

\begin{tabular}{|c|c|c|c|c|}
\hline Cons. obs. & n. obs & n. firms & $\%$ firms & $\%$ cum. firms \\
\hline 2 & 6,891 & 280 & 4.27 & 4.27 \\
\hline 3 & 6,441 & 318 & 4.85 & 9.11 \\
\hline 4 & 5,989 & 410 & 6.25 & 15.36 \\
\hline 5 & 5,553 & 466 & 7.10 & 22.47 \\
\hline 6 & 5,087 & 336 & 5.12 & 27.59 \\
\hline 7 & 4,751 & 353 & 5.38 & 32.97 \\
\hline 8 & 4,398 & 1,031 & 15.71 & 48.68 \\
\hline 9 & 3,367 & 3,367 & 51.32 & 100.00 \\
\hline Total & 49,368 & 6,561 & 100.00 & \\
\hline
\end{tabular}

Source: author's calculations.

\section{Representativeness of the sample}

A number of consistency checks have been carried on, in order to assess the representativeness of the PITEC database (manufacturing sector) and the extent to which it is comparable with other commonly used data sources.

Firstly, total employment in the manufacturing macro sector (before excluding those firms that experienced contingencies in employment records) has been compared with data from the OECD STAN Database for Structural Analysis. In STAN, information on the Number of person engaged (EMPN) and Number of employees (EMPE) in Spain is available up to 2009. The manufacturing macro sector in the sample represents about $33 \%$ of the Number of employees and about $31 \%$ of the Number of person engaged recorded in the OECD STAN database (see Table A2.

Table A2: Manufacturing - PITEC vs. OECD STAN

\begin{tabular}{llllllllll}
\hline & 2004 & 2005 & 2006 & 2007 & 2008 & 2009 & 2010 & 2011 & 2012 \\
\hline PITEC & 884,317 & 968,465 & 964,562 & 936,129 & 935,912 & 812,232 & 769,620 & 744,681 & 695,964 \\
EMPE & $2,899,300$ & $2,925,500$ & $2,904,700$ & $2,873,400$ & $2,840,400$ & $2,422,700$ & n.a & n.a & n.a \\
EMPN & $3,087,200$ & $3,106,300$ & $3,099,800$ & $3,074,100$ & $3,032,500$ & $2,594,400$ & n.a & n.a & n.a \\
\%EMPE & $30.50 \%$ & $33.10 \%$ & $33.21 \%$ & $32.58 \%$ & $32.95 \%$ & $33.53 \%$ & n.a & n.a & n.a \\
$\%$ EMPN & $28.64 \%$ & $31.18 \%$ & $31.12 \%$ & $30.45 \%$ & $30.86 \%$ & $31.31 \%$ & n.a & n.a & n.a \\
\hline
\end{tabular}

Source: author's calculations. OECD STAN Database (ISIC Rev. 3) accessed in August 2015. 
Secondly, the proportion of product and process innovators in the sample has been compared with the Spanish Community Innovation Survey (CIS 4, CIS 2006, CIS 2008, CIS 2010 and CIS 2012) ${ }^{29}$ Such comparison, reported in Table A3 shows that innovative enterprises are generally over represented in the sample under scrutiny (the proportion of product and/or process innovators in manufacturing is about two times the one recorded in CIS data for Spain). This is linked to differences in the sampling strategies.

Table A3: Manufacturing - Product and/or process innovative firms (PITEC vs. CIS)

\begin{tabular}{llll}
\hline Year & PITEC & CIS & proportion \\
\hline 2004 & $75.11 \%$ & $36.93 \%$ & 2.03 \\
2005 & $78.61 \%$ & n.a. & n.a. \\
2006 & $78.66 \%$ & $37.21 \%$ & 2.11 \\
2007 & $76.35 \%$ & n.a. & n.a. \\
2008 & $77.04 \%$ & $34.80 \%$ & 2.21 \\
2009 & $78.43 \%$ & n.a. & n.a. \\
2010 & $79.19 \%$ & $33.70 \%$ & 2.35 \\
2011 & $63.89 \%$ & n.a. & n.a. \\
2012 & $58.96 \%$ & $28.51 \%$ & 2.07 \\
\hline \multicolumn{5}{l}{ Source: author's calculations. }
\end{tabular}

\section{Industry conversion}

A probabilistic industry converter has been implemented, in order to include industry fixed effects properly taking into account the change in industrial classification (from CNAE 93 to CNAE 09), that occurred between 2008 and 2009 .

A new industry variable has been therefore created as follows. For firms that appear in the panel before 2009, the new industry variable assumes a value i) equal to their CNAE 93 code before 2009 and ii) equal to the last available CNAE 93 code for subsequent years (i.e. 2009 to 2012).

For firm that appear after 2008 a CNAE 93 industry code has been assigned, based on weighs built on the basis of changes occurred in 2008 (in the whole sample), when both classifications are observed. Few observations incurred in assignment of a new industry code (as corresponding to firms that appear in the sample for the first time after 2008).

\footnotetext{
${ }^{29}$ The sources of comparison are the official statistics produced by Eurostat based on CIS data (http://ec.europa.eu/eurostat/web/science-technology-innovation/data/database, accessed in August 2015).
} 


\section{Definition of the age variable}

The PITEC database reports information on firms' birth year starting from 2009. Birth year is then retroactively attributed to continuing firms observed before 2009. A cleaning procedure is then applied, correcting implausible values of the age variable (for instance replacing the year of birth with the first year of appearance whenever the birth year was subsequent to the first year of appearance).

Whenever differences in reported birth years for a given firm were encountered, we adopted the following strategy. If the differences in the reported year of birth for a given firm over time are higher than 2 years, the age variable has been coded as missing. Whenever the same difference is lower or equal to 2 years, the minimum value of the year of birth has been used.

Data availability and cleaning result in 708 firms having missing age.

\section{Descriptive statistics - Innovation variables}

Descriptive statistics of new-to-the-market product innovation and process innovation variables are presented in Table A4. Such descriptive statistics refer to the entire panel, as presented in Table A1.

Table A4: Summary statistics - Innovation variables

\begin{tabular}{lllllllll}
\hline variable & Obs. & min & mean & $\max$ & $\mathrm{p} 25$ & $\mathrm{p} 50$ & $\mathrm{p} 75$ & st. dev. \\
\hline ProdInn & 49,368 & 0 & 0.334 & 1 & 0 & 0 & 1 & 0.472 \\
ProcInn & 49,368 & 0 & 0.582 & 1 & 0 & 1 & 1 & 0.493 \\
ProdInn (goods) & 49,368 & 0 & 0.318 & 1 & 0 & 0 & 1 & 0.466 \\
ProdInn (services) & 49,368 & 0 & 0.115 & 1 & 0 & 0 & 0 & 0.319 \\
ProcInn (methods) & 49,368 & 0 & 0.480 & 1 & 0 & 0 & 1 & 0.500 \\
ProcInn (logistics) & 49,368 & 0 & 0.137 & 1 & 0 & 0 & 0 & 0.344 \\
ProcInn (auxiliary) & 49,368 & 0 & 0.294 & 1 & 0 & 0 & 1 & 0.456 \\
\hline
\end{tabular}

Source: author's calculations. 


\section{GMM vs. Pooled OLS}

In this subsection, the main model is estimated also by means of Pooled OLS.

Table A5: Baseline

\begin{tabular}{lccc}
\hline & $(1)$ & $(2)$ & $($ OLS $)$ \\
\hline$G_{i, t-1}$ & $-0.0519^{* * *}$ & $-0.0505^{* * *}$ & -0.0239 \\
& $(0.0188)$ & $(0.0185)$ & $(0.0168)$ \\
ProdInn $_{i, t}$ & $0.0149^{* *}$ & $0.0165^{* * *}$ & $0.0130^{* * *}$ \\
& $(0.00642)$ & $(0.00573)$ & $(0.00244)$ \\
ProcInn $_{i, t}$ & 0.00397 & 0.00667 & $0.0218^{* * *}$ \\
& $(0.00955)$ & $(0.00660)$ & $(0.00248)$ \\
log $\left(\right.$ age $\left._{i, t}\right)$ & $-0.0557^{* * *}$ & $-0.0563^{* * *}$ & $-0.00593^{* * *}$ \\
& $(0.0214)$ & $(0.0183)$ & $(0.00194)$ \\
group \\
& -0.0121 & $-0.0133^{*}$ & $0.00441^{*}$ \\
& $(0.00797)$ & $(0.00741)$ & $(0.00234)$ \\
Industry dummies & YES & NO & YES \\
Year dummies & YES & YES & YES \\
& & & \\
\hline Observations & 28,775 & 28,775 & 34,521 \\
Hansen p value & 0.364 & 0.340 & - \\
AR1 p value & 0 & 0 & - \\
AR2 p value & 0.433 & 0.384 & - \\
Number of instruments & 57 & 30 & - \\
\hline
\end{tabular}

Notes: Robust (two-step for GMM) standard error in parentheses.

*** $\mathrm{p}<0.01,{ }^{* *} \mathrm{p}<0.05,{ }^{*} \mathrm{p}<0.1$ 


\section{Quantile regression results}

Estimates at 5 points of the conditional distribution of the dependent variable (namely, the 15th, 30th, 50th, 70th and 85th percentiles) are reported below. Table A6 refers to the main specification while in Table A7 innovation variables are split in different dummies. Conditional quantiles are estimated separately. Robust and clustered standard errors are reported in parentheses, following Parente and Santos Silva (2016).

Table A6: Quantile regression results

\begin{tabular}{lccccc}
\hline & $(1)$ & $(2)$ & $(3)$ & $(4)$ & $(5)$ \\
Quantile & $\mathbf{1 5}$ & $\mathbf{3 0}$ & $\mathbf{. 5 0}$ & $\mathbf{. 7 0}$ & $\mathbf{8 5}$ \\
\hline$G_{i, t-1}$ & $0.0643^{* * *}$ & $0.0369^{* * *}$ & $0.00603^{* * *}$ & $0.0114^{* * *}$ & -0.0125 \\
& $(0.00944)$ & $(0.00450)$ & $(0.00227)$ & $(0.00383)$ & $(0.00946)$ \\
ProdInn $_{i, t}$ & $0.0177^{* * *}$ & $0.0108^{* * *}$ & $0.00319^{* * *}$ & $0.00642^{* * *}$ & $0.0110^{* * *}$ \\
& $(0.00332)$ & $(0.00189)$ & $(0.000789)$ & $(0.00144)$ & $(0.00258)$ \\
ProcInn $_{i, t}$ & $0.0341^{* * *}$ & $0.0147^{* * *}$ & $0.00286^{* * *}$ & $0.00667^{* * *}$ & 0.00383 \\
& $(0.00400)$ & $(0.00216)$ & $(0.000764)$ & $(0.00130)$ & $(0.00255)$ \\
log $\left(\right.$ age $\left._{i, t}\right)$ & $0.0234^{* * *}$ & $0.00438^{* * *}$ & $-0.00371^{* * *}$ & $-0.0136^{* * *}$ & $-0.0388^{* * *}$ \\
& $(0.00281)$ & $(0.00156)$ & $(0.000634)$ & $(0.00123)$ & $(0.00203)$ \\
group $_{i, t}$ & $0.0180^{* * *}$ & $0.00535^{* * *}$ & $-0.00249^{* * *}$ & $-0.00274^{* *}$ & $-0.0100^{* * *}$ \\
& $(0.00361)$ & $(0.00196)$ & $(0.000849)$ & $(0.00132)$ & $(0.00258)$ \\
Constant $^{*}$ & $-0.445^{* * *}$ & $-0.182^{* * *}$ & $-0.0874^{* * *}$ & -0.0100 & $0.0931^{* * *}$ \\
& $(0.0144)$ & $(0.0169)$ & $(0.00449)$ & $(0.00874)$ & $(0.0234)$ \\
Industry dummies & YES & YES & YES & YES & YES \\
Year dummies & YES & YES & YES & YES & YES \\
\hline Observations & 34,521 & 34,521 & 34,521 & 34,521 & 34,521 \\
Pseudo R-squared & 0.031 & 0.036 & 0.033 & 0.031 & 0.020 \\
\hline
\end{tabular}

Notes: Robust clustered standard errors in parentheses *** $\mathrm{p}<0.01,{ }^{* *} \mathrm{p}<0.05,{ }^{*} \mathrm{p}<0.1$ 
Table A7: Quantile regression results - Splitting innovation variables

\begin{tabular}{|c|c|c|c|c|c|}
\hline & (1) & (2) & (3) & $(4)$ & (5) \\
\hline Quantile & .15 & .30 & .50 & .70 & .85 \\
\hline$G_{i, t-1}$ & $\begin{array}{c}0.0659^{* * *} \\
(0.0104)\end{array}$ & $\begin{array}{c}0.0380^{* * *} \\
(0.00441)\end{array}$ & $\begin{array}{c}0.00574^{* *} \\
(0.00225)\end{array}$ & $\begin{array}{l}0.0113^{* * *} \\
(0.00395)\end{array}$ & $\begin{array}{c}-0.0137 \\
(0.00988)\end{array}$ \\
\hline $\operatorname{ProdInn}_{i, t}($ goods $)$ & $\begin{array}{c}0.0190^{* * *} \\
(0.00387)\end{array}$ & $\begin{array}{c}0.0102^{* * *} \\
(0.00207)\end{array}$ & $\begin{array}{c}0.00281^{* * *} \\
(0.000844)\end{array}$ & $\begin{array}{c}0.00556^{* * * *} \\
(0.00159)\end{array}$ & $\begin{array}{c}0.00966^{* * *} \\
(0.00282)\end{array}$ \\
\hline $\operatorname{ProdInn}_{i, t}($ services $)$ & $\begin{array}{l}-0.00647 \\
(0.00537)\end{array}$ & $\begin{array}{l}-6.75 \mathrm{e}-05 \\
(0.00301)\end{array}$ & $\begin{array}{c}0.00135 \\
(0.00121)\end{array}$ & $\begin{array}{c}0.00189 \\
(0.00263)\end{array}$ & $\begin{array}{c}0.00316 \\
(0.00419)\end{array}$ \\
\hline ProcInn $_{i, t}$ (methods) & $\begin{array}{c}0.0243^{* * *} \\
(0.00380)\end{array}$ & $\begin{array}{c}0.0105^{* * *} \\
(0.00194)\end{array}$ & $\begin{array}{l}0.00159^{* *} \\
(0.000767)\end{array}$ & $\begin{array}{c}0.00476^{* * * *} \\
(0.00130)\end{array}$ & $\begin{array}{l}0.000233 \\
(0.00248)\end{array}$ \\
\hline $\operatorname{ProcInn}_{i, t}$ (logistics) & $\begin{array}{c}0.00199 \\
(0.00460)\end{array}$ & $\begin{array}{l}0.000786 \\
(0.00236)\end{array}$ & $\begin{array}{l}0.000431 \\
(0.00123)\end{array}$ & $\begin{array}{l}-0.000414 \\
(0.00188)\end{array}$ & $\begin{array}{l}-0.00134 \\
(0.00342)\end{array}$ \\
\hline $\operatorname{ProcInn}_{i, t}($ auxiliary $)$ & $\begin{array}{c}0.0142^{* * *} \\
(0.00350)\end{array}$ & $\begin{array}{c}0.00564^{* * * *} \\
(0.00200)\end{array}$ & $\begin{array}{c}0.00258^{* * *} \\
(0.000884)\end{array}$ & $\begin{array}{c}0.00532^{* * *} \\
(0.00157)\end{array}$ & $\begin{array}{c}0.00628^{* *} \\
(0.00272)\end{array}$ \\
\hline $\log \left(a g e_{i, t}\right)$ & $\begin{array}{c}0.0233^{* * *} \\
(0.00279)\end{array}$ & $\begin{array}{c}0.00400^{* * * *} \\
(0.00154)\end{array}$ & $\begin{array}{c}-0.00391^{* * *} \\
(0.000641)\end{array}$ & $\begin{array}{c}-0.0135^{* * *} \\
(0.00125)\end{array}$ & $\begin{array}{c}-0.0392^{* * *} \\
(0.00206)\end{array}$ \\
\hline $\operatorname{group}_{i, t}$ & $\begin{array}{c}0.0166^{* * *} \\
(0.00370)\end{array}$ & $\begin{array}{c}0.00507^{* * *} \\
(0.00196)\end{array}$ & $\begin{array}{c}-0.00247^{* * *} \\
(0.000848)\end{array}$ & $\begin{array}{c}-0.00302^{* *} \\
(0.00133)\end{array}$ & $\begin{array}{c}-0.00981^{* * * *} \\
(0.00256)\end{array}$ \\
\hline Constant & $\begin{array}{c}-0.287^{* * *} \\
(0.0269)\end{array}$ & $\begin{array}{c}-0.0924^{* * *} \\
(0.0126)\end{array}$ & $\begin{array}{c}0.0183^{* * *} \\
(0.00668)\end{array}$ & $\begin{array}{c}0.0446^{* * *} \\
(0.00960)\end{array}$ & $\begin{array}{l}0.174^{* * *} \\
(0.0167)\end{array}$ \\
\hline Industry dummies & YES & YES & YES & YES & YES \\
\hline Year dummies & YES & YES & YES & YES & YES \\
\hline Observations & 34,521 & 34,521 & 34,521 & 34,521 & 34,521 \\
\hline Pseudo R-squared & 0.031 & 0.035 & 0.033 & 0.031 & 0.020 \\
\hline
\end{tabular}

Notes: Robust clustered standard errors in parentheses

*** $\mathrm{p}<0.01,{ }^{* *} \mathrm{p}<0.05,{ }^{*} \mathrm{p}<0.1$ 


\section{Robustness: Different employment growth measure}

In this section a replication of estimates using a different definition of employment growth (so-called job flows measure, as previously defined) are presented. Table A8 presents GMM estimates, Table A9 and A10 quantile regression estimates.

Table A8: GMM estimates - different employment growth measure

\begin{tabular}{|c|c|c|c|c|}
\hline & (1) & $(2)$ & $(3)$ & (4) \\
\hline$g_{i, t-1}$ & $\begin{array}{c}-0.0418^{* * *} \\
(0.0151)\end{array}$ & $\begin{array}{c}-0.0399^{* * *} \\
(0.0146)\end{array}$ & $\begin{array}{c}-0.0447^{* * *} \\
(0.0147)\end{array}$ & $\begin{array}{c}-0.0406^{* * *} \\
(0.0141)\end{array}$ \\
\hline $\operatorname{ProdInn}_{i, t}$ & $\begin{array}{l}0.0148^{* *} \\
(0.00601)\end{array}$ & $\begin{array}{c}0.0162^{* * * *} \\
(0.00543)\end{array}$ & $\begin{array}{l}- \\
-\end{array}$ & $\begin{array}{l}- \\
-\end{array}$ \\
\hline $\operatorname{ProcInn}_{i, t}$ & $\begin{array}{c}0.00441 \\
(0.00886)\end{array}$ & $\begin{array}{c}0.00706 \\
(0.00615)\end{array}$ & $\begin{array}{l}- \\
-\end{array}$ & $\begin{array}{l}- \\
-\end{array}$ \\
\hline ProdInn $_{i, t}($ goods $)$ & - & - & $\begin{array}{l}0.0132^{* *} \\
(0.00619)\end{array}$ & $\begin{array}{l}0.0171^{* * *} \\
(0.00559)\end{array}$ \\
\hline $\operatorname{ProdInn}_{i, t}($ services $)$ & $\begin{array}{l}- \\
-\end{array}$ & $\begin{array}{l}- \\
-\end{array}$ & $\begin{array}{l}0.000437 \\
(0.00700)\end{array}$ & $\begin{array}{l}-0.00154 \\
(0.00690)\end{array}$ \\
\hline ProcInn $_{i, t}$ (methods) & $\begin{array}{l}- \\
-\end{array}$ & $\begin{array}{l}- \\
-\end{array}$ & $\begin{array}{l}-0.00282 \\
(0.00671)\end{array}$ & $\begin{array}{c}0.00203 \\
(0.00525)\end{array}$ \\
\hline $\operatorname{ProcInn}_{i, t}$ (logistics) & $\begin{array}{l}- \\
-\end{array}$ & $\begin{array}{l}- \\
-\end{array}$ & $\begin{array}{c}0.00673 \\
(0.00699)\end{array}$ & $\begin{array}{c}0.00629 \\
(0.00689)\end{array}$ \\
\hline ProcInn $_{i, t}$ (auxiliary) & $\begin{array}{l}- \\
-\end{array}$ & $\begin{array}{l}- \\
-\end{array}$ & $\begin{array}{c}0.0103^{*} \\
(0.00564)\end{array}$ & $\begin{array}{l}0.0103^{* *} \\
(0.00502)\end{array}$ \\
\hline $\log \left(a g e_{i, t}\right)$ & $\begin{array}{c}-0.0514^{* *} \\
(0.0201)\end{array}$ & $\begin{array}{c}-0.0517^{* * *} \\
(0.0172)\end{array}$ & $\begin{array}{c}-0.0525^{* * *} \\
(0.0200)\end{array}$ & $\begin{array}{c}-0.0525^{* * *} \\
(0.0170)\end{array}$ \\
\hline $\operatorname{group}_{i, t}$ & $\begin{array}{c}-0.0103 \\
(0.00755)\end{array}$ & $\begin{array}{c}-0.0114 \\
(0.00701)\end{array}$ & $\begin{array}{c}-0.0101 \\
(0.00727)\end{array}$ & $\begin{array}{c}-0.0114 \\
(0.00695)\end{array}$ \\
\hline $\begin{array}{l}\text { Industry dummies } \\
\text { Year dummies }\end{array}$ & $\begin{array}{l}\text { YES } \\
\text { YES }\end{array}$ & $\begin{array}{l}\mathrm{NO} \\
\mathrm{YES}\end{array}$ & $\begin{array}{l}\text { YES } \\
\text { YES }\end{array}$ & $\begin{array}{r}\mathrm{NO} \\
\mathrm{YES}\end{array}$ \\
\hline Observations & 28,775 & 28,775 & 28,775 & 28,775 \\
\hline Hansen $\mathrm{p}$ value & 0.273 & 0.255 & 0.585 & 0.465 \\
\hline AR1 $\mathrm{p}$ value & 0 & 0 & 0 & 0 \\
\hline AR2 p value & 0.487 & 0.397 & 0.644 & 0.415 \\
\hline Number of instruments & 57 & 30 & 81 & 54 \\
\hline
\end{tabular}

Notes: Robust two-step standard errors in parentheses $* * * \mathrm{p}<0.01,{ }^{* *} \mathrm{p}<0.05, * \mathrm{p}<0.1$ 
Table A9: Quantile regression - different employment growth measure

\begin{tabular}{lccccc}
\hline & $(1)$ & $(2)$ & $(3)$ & $(4)$ & $(5)$ \\
Quantile & $\mathbf{. 5}$ & $\mathbf{. 3 0}$ & $\mathbf{. 5 0}$ & $\mathbf{. 7 0}$ & $\mathbf{. 8 5}$ \\
\hline$g_{i, t-1}$ & $0.0724^{* * *}$ & $0.0434^{* * *}$ & $0.00789^{* * *}$ & $0.0131^{* * *}$ & -0.00915 \\
& $(0.0120)$ & $(0.00660)$ & $(0.00250)$ & $(0.00376)$ & $(0.0106)$ \\
ProdInn $_{i, t}$ & $0.0175^{* * *}$ & $0.0109^{* * *}$ & $0.00318^{* * *}$ & $0.00631^{* * *}$ & $0.0110^{* * *}$ \\
& $(0.00333)$ & $(0.00190)$ & $(0.000792)$ & $(0.00143)$ & $(0.00255)$ \\
ProcInn $_{i, t}$ & $0.0342^{* * *}$ & $0.0145^{* * *}$ & $0.00291^{* * *}$ & $0.00667^{* * *}$ & 0.00392 \\
& $(0.00395)$ & $(0.00210)$ & $(0.000770)$ & $(0.00130)$ & $(0.00252)$ \\
log$\left(\right.$ age $\left._{i, t}\right)$ & $0.0237^{* * *}$ & $0.00442^{* * *}$ & $-0.00367^{* * *}$ & $-0.0136^{* * *}$ & $-0.0385^{* * *}$ \\
& $(0.00280)$ & $(0.00156)$ & $(0.000635)$ & $(0.00122)$ & $(0.00203)$ \\
group $_{i, t}$ & $0.0179^{* * *}$ & $0.00531^{* * *}$ & $-0.00257^{* * *}$ & $-0.00278^{* *}$ & $-0.0101^{* * *}$ \\
& $(0.00357)$ & $(0.00192)$ & $(0.000851)$ & $(0.00131)$ & $(0.00254)$ \\
Constant & $-0.444^{* * *}$ & $-0.181^{* * *}$ & $-0.0871^{* * *}$ & -0.00910 & $0.0922^{* * *}$ \\
& $(0.0143)$ & $(0.0169)$ & $(0.00450)$ & $(0.00872)$ & $(0.0234)$ \\
Industry dummies & YES & YES & YES & YES & YES \\
Year dummies & YES & YES & YES & YES & YES \\
\hline Observations & 34,521 & 34,521 & 34,521 & 34,521 & 34,521 \\
Pseudo R-squared & 0.036 & 0.041 & 0.038 & 0.036 & 0.023 \\
\hline
\end{tabular}

Notes: Robust clustered standard errors in parentheses

*** $\mathrm{p}<0.01,{ }^{* *} \mathrm{p}<0.05,{ }^{*} \mathrm{p}<0.1$ 
Table A10: Quantile regression - different employment growth measure (splitting innovation variables)

\begin{tabular}{|c|c|c|c|c|c|}
\hline & (1) & (2) & $(3)$ & $(4)$ & $(5)$ \\
\hline Quantile & .15 & .30 & .50 & .70 & .85 \\
\hline$g_{i, t-1}$ & $\begin{array}{c}0.0746^{* * *} \\
(0.0124)\end{array}$ & $\begin{array}{c}0.0452^{* * *} \\
(0.00684)\end{array}$ & $\begin{array}{c}0.00752^{* * *} \\
(0.00246)\end{array}$ & $\begin{array}{c}0.0135^{* * *} \\
(0.00401)\end{array}$ & $\begin{array}{l}-0.0109 \\
(0.0114)\end{array}$ \\
\hline $\operatorname{ProdInn}_{i, t}($ goods $)$ & $\begin{array}{c}0.0192^{* * * *} \\
(0.00366)\end{array}$ & $\begin{array}{c}0.0103^{* * *} \\
(0.00206)\end{array}$ & $\begin{array}{c}0.00282^{* * *} \\
(0.000843)\end{array}$ & $\begin{array}{c}0.00548^{* * *} \\
(0.00157)\end{array}$ & $\begin{array}{c}0.00982^{* * *} \\
(0.00283)\end{array}$ \\
\hline $\operatorname{ProdInn}_{i, t}($ services $)$ & $\begin{array}{l}-0.00662 \\
(0.00492)\end{array}$ & $\begin{array}{l}-0.000146 \\
(0.00297)\end{array}$ & $\begin{array}{c}0.00141 \\
(0.00121)\end{array}$ & $\begin{array}{c}0.00194 \\
(0.00261)\end{array}$ & $\begin{array}{c}0.00307 \\
(0.00421)\end{array}$ \\
\hline ProcInn $_{i, t}$ (methods) & $\begin{array}{c}0.0241^{* * *} \\
(0.00363)\end{array}$ & $\begin{array}{c}0.0105^{* * *} \\
(0.00194)\end{array}$ & $\begin{array}{l}0.00162^{* *} \\
(0.000770)\end{array}$ & $\begin{array}{c}0.00480^{* * *} \\
(0.00130)\end{array}$ & $\begin{array}{l}0.000193 \\
(0.00247)\end{array}$ \\
\hline $\operatorname{ProcInn}_{i, t}$ (logistics) & $\begin{array}{c}0.00181 \\
(0.00441)\end{array}$ & $\begin{array}{l}0.000696 \\
(0.00239)\end{array}$ & $\begin{array}{l}0.000325 \\
(0.00124)\end{array}$ & $\begin{array}{l}-0.000418 \\
(0.00188)\end{array}$ & $\begin{array}{l}-0.00100 \\
(0.00339)\end{array}$ \\
\hline $\operatorname{ProcInn}_{i, t}$ (auxiliary) & $\begin{array}{c}0.0140^{* * *} \\
(0.00336)\end{array}$ & $\begin{array}{c}0.00566^{* * *} \\
(0.00200)\end{array}$ & $\begin{array}{c}0.00264 * * * \\
(0.000884)\end{array}$ & $\begin{array}{c}0.00518^{* * *} \\
(0.00156)\end{array}$ & $\begin{array}{l}0.00615^{* *} \\
(0.00271)\end{array}$ \\
\hline $\log \left(a g e_{i, t}\right)$ & $\begin{array}{c}0.0234^{* * *} \\
(0.00270)\end{array}$ & $\begin{array}{c}0.00408^{* * *} \\
(0.00153)\end{array}$ & $\begin{array}{c}-0.00387^{* * *} \\
(0.000639)\end{array}$ & $\begin{array}{c}-0.0135^{* * *} \\
(0.00124)\end{array}$ & $\begin{array}{c}-0.0390^{* * *} \\
(0.00202)\end{array}$ \\
\hline $\operatorname{group}_{i, t}$ & $\begin{array}{c}0.0169^{* * *} \\
(0.00349)\end{array}$ & $\begin{array}{c}0.00497^{* *} \\
(0.00197)\end{array}$ & $\begin{array}{c}-0.00249^{* * *} \\
(0.000850)\end{array}$ & $\begin{array}{c}-0.00298^{* *} \\
(0.00132)\end{array}$ & $\begin{array}{c}-0.00975^{* * *} \\
(0.00254)\end{array}$ \\
\hline Constant & $\begin{array}{c}-0.285^{* * *} \\
(0.0264)\end{array}$ & $\begin{array}{c}-0.0936^{* * *} \\
(0.0128)\end{array}$ & $\begin{array}{c}0.0168^{* * *} \\
(0.00501)\end{array}$ & $\begin{array}{c}0.0448^{* * *} \\
(0.00957)\end{array}$ & $\begin{array}{l}0.171^{* * *} \\
(0.0165)\end{array}$ \\
\hline Industry dummies & YES & YES & YES & YES & YES \\
\hline Year dummies & YES & YES & YES & YES & YES \\
\hline Observations & 34,521 & 34,521 & 34,521 & 34,521 & 34,521 \\
\hline Pseudo R-squared & 0.036 & 0.041 & 0.038 & 0.036 & 0.023 \\
\hline
\end{tabular}




\section{Robustness: Different product innovation measure}

In Table A11 and A12 we use a different measure of product innovation $\log \left(\operatorname{TurnProdInn}_{i, t}\right)$, which identifies the $(\log )$ turnover spent for new-to-the-market product innovations. This measure is unfortunately not available for process innovation (as in most innovation surveys).

Table A11: GMM estimates - different product innovation measure

\begin{tabular}{lcc}
\hline & $(1)$ & $(2)$ \\
\hline$G_{i, t-1}$ & $-0.0495^{* * *}$ & $-0.0483^{* * *}$ \\
$\log \left(\right.$ TurnProdInn $\left._{i, t}\right)$ & $(0.0189)$ & $(0.0186)$ \\
& $\left(0.000431^{* * *}\right.$ & $0.00141^{* * *}$ \\
ProcInn $_{i, t}$ & 0.00376 & $(0.000405)$ \\
& $(0.00944)$ & 0.00589 \\
$\log \left(\right.$ age $\left._{i, t}\right)$ & $-0.0553^{* * *}$ & $-0.0563^{* * *}$ \\
& $(0.0207)$ & $(0.0183)$ \\
group $_{i, t}$ & -0.0124 & $-0.0135^{*}$ \\
& $(0.00790)$ & $(0.00742)$ \\
Industry dummies $_{\text {Year dummies }}$ & YES & NO \\
& YES & YES \\
\hline Observations & 28,774 & 28,774 \\
Hansen p value & 0.452 & 0.432 \\
AR1 p value & 0 & 0 \\
AR2 p value & 0.383 & 0.347 \\
Number of instruments & 57 & 30 \\
\hline
\end{tabular}

Notes: Robust two-step standard error in parentheses.

$* * * \mathrm{p}<0.01,{ }^{* *} \mathrm{p}<0.05,{ }^{*} \mathrm{p}<0.1$ 
Table A12: Quantile regression - different product innovation measure

\begin{tabular}{lccccc}
\hline & $(1)$ & $(2)$ & $(3)$ & $(4)$ & $(5)$ \\
Quantile & $\mathbf{1 5}$ & $\mathbf{3 0}$ & $\mathbf{. 5 0}$ & $\mathbf{. 7 0}$ & $\mathbf{8 5}$ \\
\hline$G_{i, t-1}$ & $0.0642^{* * *}$ & $0.0365^{* * *}$ & $0.00604^{* * *}$ & $0.0111^{* * *}$ & -0.0116 \\
$\log \left(\right.$ TurnProdInn $\left._{i, t}\right)$ & $(0.00977)$ & $(0.00634)$ & $(0.00230)$ & $(0.00385)$ & $(0.00960)$ \\
& $\left(0.0143^{* * *}\right.$ & $0.000811^{* * *}$ & $0.000272^{* * *}$ & $0.000495^{* * *}$ & $0.000788^{* * *}$ \\
ProcInn $_{i, t}$ & $0.0333^{* * *}$ & $(0.000124)$ & $(5.70 \mathrm{e}-05)$ & $(9.82 \mathrm{e}-05)$ & $(0.000169)$ \\
& $(0.00421)$ & $\left(0.002145^{* * *}\right.$ & $0.00277^{* * *}$ & $0.00652^{* * *}$ & 0.00393 \\
$\log \left(\right.$ age $\left._{i, t}\right)$ & $0.0232^{* * *}$ & $0.00409^{* * *}$ & $-0.000383^{* * *}$ & $-0.0137^{* * *}$ & $-0.00259^{* * *}$ \\
& $(0.00273)$ & $(0.00154)$ & $(0.000641)$ & $(0.00124)$ & $(0.00202)$ \\
group $_{i, t}$ & $0.0169^{* * *}$ & $0.00471^{* *}$ & $-0.00274^{* * *}$ & $-0.00297^{* *}$ & $-0.0106^{* * *}$ \\
& $(0.00369)$ & $(0.00195)$ & $(0.000860)$ & $(0.00132)$ & $(0.00259)$ \\
Constant & $-0.242^{* * *}$ & $-0.0690^{* * *}$ & $0.0265^{* * *}$ & $0.0754^{* * *}$ & $0.198^{* * *}$ \\
& $(0.0253)$ & $(0.0127)$ & $(0.00667)$ & $(0.00540)$ & $(0.0157)$ \\
Industry dummies & YES & YES & YES & YES & YES \\
Year dummies & YES & YES & YES & YES & YES \\
\hline Observations & 34,519 & 34,519 & 34,519 & 34,519 & 34,519 \\
Pseudo R-squared & 0.032 & 0.036 & 0.033 & 0.032 & 0.020 \\
\hline
\end{tabular}

Notes: Robust clustered standard errors in parentheses

$$
\text { *** } \mathrm{p}<0.01,{ }^{* *} \mathrm{p}<0.05,{ }^{*} \mathrm{p}<0.1
$$




\section{Robustness: Complementarity of Innovation Strategies}

Estimates with a different set of innovation dummies, in order to take into preliminary account the complementarities existing between product and process innovation strategies, are presented in Table A13 and A14. See the main body of text for a detailed definition.

Table A13: GMM estimates - complementarity of innovation strategies

\begin{tabular}{lcc}
\hline & $(1)$ & $(2)$ \\
\hline$G_{i, t-1}$ & $-0.0520^{* * *}$ & $-0.0504^{* * *}$ \\
& $(0.0186)$ & $(0.0185)$ \\
ProdInn $_{i, t-1}$ only & $0.0313^{* * *}$ & $0.0358^{* * *}$ \\
& $(0.0111)$ & $(0.0101)$ \\
ProcInn $_{i, t-1}$ only & 0.0109 & $0.0146^{*}$ \\
& $(0.00903)$ & $(0.00751)$ \\
ProdInn $_{i, t-1} \&$ ProcInn $_{i, t-1}$ & 0.0181 & $0.0257^{* * *}$ \\
& $(0.0122)$ & $(0.00946)$ \\
log $\left(\right.$ age $\left._{i, t}\right)$ & $-0.0492^{* *}$ & $-0.0546^{* * *}$ \\
& $(0.0217)$ & $(0.0184)$ \\
group & \\
& -0.0108 & $-0.0129^{*}$ \\
Industry dummies $_{\text {Year dummies }}$ & $(0.00782)$ & $(0.00737)$ \\
& YES & NO \\
Observations & YES & YES \\
Hansen p value & & \\
AR1 p value & 28,775 & 28,775 \\
AR2 p value & 0.119 & 0.0903 \\
Number of instruments & 0 & 0 \\
\hline
\end{tabular}

Notes: Robust two-step standard error in parentheses.

$* * * \mathrm{p}<0.01,{ }^{* *} \mathrm{p}<0.05,{ }^{*} \mathrm{p}<0.1$ 
Table A14: Quantile regression - complementarity of innovation strategies

\begin{tabular}{|c|c|c|c|c|c|}
\hline & (1) & (2) & (3) & $(4)$ & $(5)$ \\
\hline Quantile & .15 & .30 & .50 & .70 & .85 \\
\hline$G_{i, t-1}$ & $\begin{array}{c}0.0639^{* * *} \\
(0.00909)\end{array}$ & $\begin{array}{c}0.0374^{* * *} \\
(0.00441)\end{array}$ & $\begin{array}{c}0.00604^{* * *} \\
(0.00226)\end{array}$ & $\begin{array}{c}0.0112^{* * *} \\
(0.00383)\end{array}$ & $\begin{array}{c}-0.0127 \\
(0.00955)\end{array}$ \\
\hline $\operatorname{ProdInn}_{i, t-1}$ only & $\begin{array}{c}0.0382^{* * *} \\
(0.00751)\end{array}$ & $\begin{array}{c}0.0206^{* * *} \\
(0.00361)\end{array}$ & $\begin{array}{c}0.00301^{* *} \\
(0.00119)\end{array}$ & $\begin{array}{c}0.00849^{* * * *} \\
(0.00279)\end{array}$ & $\begin{array}{r}0.0150^{* * * *} \\
(0.00496)\end{array}$ \\
\hline $\operatorname{ProcInn}_{i, t-1}$ only & $\begin{array}{c}0.0397^{* * *} \\
(0.00463)\end{array}$ & $\begin{array}{c}0.0182^{* * *} \\
(0.00249)\end{array}$ & $\begin{array}{c}0.00281^{* * *} \\
(0.000905)\end{array}$ & $\begin{array}{c}0.00725^{* * *} \\
(0.00139)\end{array}$ & $\begin{array}{l}0.00519^{*} \\
(0.00292)\end{array}$ \\
\hline $\operatorname{ProdInn}_{i, t-1} \& \operatorname{ProcInn}_{i, t-1}$ & $\begin{array}{c}0.0531^{* * *} \\
(0.00482)\end{array}$ & $\begin{array}{c}0.0256^{* * *} \\
(0.00266)\end{array}$ & $\begin{array}{c}0.00603^{* * *} \\
(0.00103)\end{array}$ & $\begin{array}{c}0.0129^{* * *} \\
(0.00166)\end{array}$ & $\begin{array}{c}0.0147^{* * *} \\
(0.00313)\end{array}$ \\
\hline $\log \left(a g e_{i, t}\right)$ & $\begin{array}{c}0.0231^{* * *} \\
(0.00271)\end{array}$ & $\begin{array}{c}0.00440^{* * *} \\
(0.00152)\end{array}$ & $\begin{array}{c}-0.00370^{* * *} \\
(0.000632)\end{array}$ & $\begin{array}{c}-0.0136^{* * *} \\
(0.00123)\end{array}$ & $\begin{array}{r}-0.0388^{* * *} \\
(0.00200)\end{array}$ \\
\hline group $_{i, t}$ & $\begin{array}{c}0.0183^{* * *} \\
(0.00350)\end{array}$ & $\begin{array}{c}0.00498^{* * *} \\
(0.00187)\end{array}$ & $\begin{array}{c}-0.00248 * * * \\
(0.000848)\end{array}$ & $\begin{array}{c}-0.00274^{* *} \\
(0.00132)\end{array}$ & $\begin{array}{c}-0.0101^{* * *} \\
(0.00254)\end{array}$ \\
\hline Constant & $\begin{array}{c}-0.398^{* * *} \\
(0.0131)\end{array}$ & $\begin{array}{c}-0.162^{* * *} \\
(0.0171)\end{array}$ & $\begin{array}{c}-0.0797^{* * *} \\
(0.00454)\end{array}$ & $\begin{array}{l}0.0179^{* *} \\
(0.00882)\end{array}$ & $\begin{array}{l}0.122^{* * *} \\
(0.0235)\end{array}$ \\
\hline Industry dummies & YES & YES & YES & YES & YES \\
\hline Year dummies & YES & YES & YES & YES & YES \\
\hline Observations & 34,521 & 34,521 & 34,521 & 34,521 & 34,521 \\
\hline Pseudo R-squared & 0.032 & 0.036 & 0.033 & 0.031 & 0.020 \\
\hline
\end{tabular}

Notes: Robust clustered standard errors in parentheses

*** $\mathrm{p}<0.01,{ }^{* *} \mathrm{p}<0.05,{ }^{*} \mathrm{p}<0.1$ 


\section{Robustness: GMM - Predetermined group variable}

Estimates specifying the group variable as predetermined are reported in Table $\mathrm{A} 15{ }^{30}$

Table A15: GMM estimates - Predetermined group variable

\begin{tabular}{|c|c|c|c|c|}
\hline & (1) & $(2)$ & $(3)$ & $(4)$ \\
\hline$G_{i, t-1}$ & $\begin{array}{c}-0.0488^{* * *} \\
(0.0183)\end{array}$ & $\begin{array}{c}-0.0469 * * \\
(0.0183)\end{array}$ & $\begin{array}{c}-0.0467^{* * *} \\
(0.0171)\end{array}$ & $\begin{array}{c}-0.0449 * * * \\
(0.0170)\end{array}$ \\
\hline $\operatorname{ProdInn}_{i, t}$ & $\begin{array}{c}0.0130^{*} \\
(0.00668)\end{array}$ & $\begin{array}{c}0.0171^{* * *} \\
(0.00578)\end{array}$ & $\begin{array}{l}- \\
-\end{array}$ & $\begin{array}{l}- \\
-\end{array}$ \\
\hline $\operatorname{ProcInn}_{i, t}$ & $\begin{array}{c}0.00195 \\
(0.00779)\end{array}$ & $\begin{array}{c}0.00596 \\
(0.00655)\end{array}$ & - & - \\
\hline $\operatorname{ProdInn}_{i, t}($ goods $)$ & - & $\begin{array}{l}- \\
-\end{array}$ & $\begin{array}{l}0.0134^{* *} \\
(0.00681)\end{array}$ & $\begin{array}{c}0.0179 * * * \\
(0.00590)\end{array}$ \\
\hline $\operatorname{ProdInn}_{i, t}($ services $)$ & $\begin{array}{l}- \\
-\end{array}$ & $\begin{array}{l}- \\
-\end{array}$ & $\begin{array}{l}-2.71 \mathrm{e}-05 \\
(0.00741)\end{array}$ & $\begin{array}{l}-0.00221 \\
(0.00722)\end{array}$ \\
\hline $\operatorname{ProcInn}_{i, t}$ (methods) & $\begin{array}{l}- \\
-\end{array}$ & $\begin{array}{l}- \\
-\end{array}$ & $\begin{array}{l}-0.00142 \\
(0.00610)\end{array}$ & $\begin{array}{l}0.000825 \\
(0.00556)\end{array}$ \\
\hline $\operatorname{ProcInn}_{i, t}($ logistics $)$ & $\begin{array}{l}- \\
-\end{array}$ & $\begin{array}{l}- \\
-\end{array}$ & $\begin{array}{c}0.00429 \\
(0.00792)\end{array}$ & $\begin{array}{c}0.00657 \\
(0.00746)\end{array}$ \\
\hline $\operatorname{ProcInn}_{i, t}($ auxiliary $)$ & $\begin{array}{l}- \\
-\end{array}$ & - & $\begin{array}{c}0.0109 * \\
(0.00573)\end{array}$ & $\begin{array}{c}0.0101^{*} \\
(0.00532)\end{array}$ \\
\hline $\log \left(a g e_{i, t}\right)$ & $\begin{array}{c}-0.0452^{* *} \\
(0.0216)\end{array}$ & $\begin{array}{c}-0.0538^{* * *} \\
(0.0183)\end{array}$ & $\begin{array}{c}-0.0522^{* *} \\
(0.0209)\end{array}$ & $\begin{array}{c}-0.0540^{* * *} \\
(0.0181)\end{array}$ \\
\hline $\operatorname{group}_{i, t}$ & $\begin{array}{c}0.0134 \\
(0.0296)\end{array}$ & $\begin{array}{c}0.0287 \\
(0.0269)\end{array}$ & $\begin{array}{l}0.00850 \\
(0.0286)\end{array}$ & $\begin{array}{c}0.0232 \\
(0.0265)\end{array}$ \\
\hline $\begin{array}{l}\text { Industry dummies } \\
\text { Year dummies }\end{array}$ & $\begin{array}{l}\text { YES } \\
\text { YES }\end{array}$ & $\begin{array}{c}\mathrm{NO} \\
\mathrm{YES}\end{array}$ & $\begin{array}{l}\text { YES } \\
\text { YES }\end{array}$ & $\begin{array}{r}\mathrm{NO} \\
\mathrm{YES}\end{array}$ \\
\hline Observations & 28,775 & 28,775 & 28,775 & 28,775 \\
\hline Hansen $\mathrm{p}$ value & 0.424 & 0.343 & 0.688 & 0.592 \\
\hline AR1 p value & 0 & 0 & 0 & 0 \\
\hline AR2 $\mathrm{p}$ value & 0.405 & 0.327 & 0.406 & 0.310 \\
\hline Number of instruments & 63 & 36 & 87 & 60 \\
\hline
\end{tabular}

Standard errors in parentheses

*** $\mathrm{p}<0.01, * * \mathrm{p}<0.05, * \mathrm{p}<0.1$

${ }^{30}$ Guided by a Difference in Hansen test the last lag of the group variable is not used as instrument. 


\section{Robustness: GMM - Endogenous innovation variables}

Estimates specifying innovation variables as endogenous are reported in Table A16, for reference only. In columns (1) and (3) other controls are specified as exogenous, as in Table 1; in columns (2) and (4) group is predetermined, as in Table A15.

Table A16: GMM estimates - endogenous innovation variables

\begin{tabular}{lcccc}
\hline & $(1)$ & $(2)$ & $(3)$ & $(4)$ \\
\hline$G_{i, t-1}$ & $-0.0434^{* *}$ & $-0.0374^{*}$ & $-0.0510^{* * *}$ & $-0.0481^{* * *}$ \\
& $(0.0210)$ & $(0.0198)$ & $(0.0183)$ & $(0.0181)$ \\
ProdInn $_{i, t}$ & $0.0361^{*}$ & $0.0362^{* *}$ & 0.0160 & $0.0178^{*}$ \\
& $(0.0206)$ & $(0.0174)$ & $(0.00979)$ & $(0.00981)$ \\
ProcInn $_{i, t}$ & 0.00455 & 0.00493 & 0.00247 & 0.00139 \\
& $(0.00960)$ & $(0.00856)$ & $(0.00844)$ & $(0.00833)$ \\
log $\left(\right.$ age $\left._{i, t}\right)$ & $-0.0905^{* *}$ & $-0.0875^{* * *}$ & $-0.0563^{* * *}$ & $-0.0539^{* * *}$ \\
& $(0.0366)$ & $(0.0313)$ & $(0.0183)$ & $(0.0184)$ \\
group $_{i, t}$ & $-0.0198^{* *}$ & 0.0450 & $-0.0132^{*}$ & 0.0280 \\
& $(0.00993)$ & $(0.0314)$ & $(0.00742)$ & $(0.0269)$ \\
Industry dummies & YES & YES & NO & NO \\
Year dummies & YES & YES & YES & YES \\
& & & & \\
\hline Observations & 28,775 & 28,775 & 28,775 & 28,775 \\
Hansen p value & 0.286 & 0.350 & 0.225 & 0.259 \\
AR1 p value & 0 & 0 & 0 & 0 \\
AR2 p value & 0.409 & 0.275 & 0.387 & 0.340 \\
Number of instruments & 55 & 61 & 28 & 34 \\
\hline
\end{tabular}

Standard errors in parentheses

$* * * \mathrm{p}<0.01,{ }^{* *} \mathrm{p}<0.05,{ }^{*} \mathrm{p}<0.1$ 


\section{Robustness: Quantile regression - Lagged innovation variables}

The quantile regression estimates have been replicated in Table A17 and A18, substituting to the innovation dummies their first lag, in order to take into (partial) account simultaneity issues.

Table A17: Quantile regression - Lagged innovation variables

\begin{tabular}{|c|c|c|c|c|c|}
\hline & (1) & (2) & (3) & $(4)$ & (5) \\
\hline Quantile & .15 & .30 & .50 & .70 & .85 \\
\hline$G_{i, t-1}$ & $\begin{array}{c}0.0641^{* * *} \\
(0.00902)\end{array}$ & $\begin{array}{c}0.0368^{* * *} \\
(0.00570)\end{array}$ & $\begin{array}{c}0.00636^{* * *} \\
(0.00219)\end{array}$ & $\begin{array}{c}0.0136^{* * *} \\
(0.00378)\end{array}$ & $\begin{array}{c}-0.0114 \\
(0.00857)\end{array}$ \\
\hline $\operatorname{ProdInn}_{i, t-1}$ & $\begin{array}{c}0.0143^{* * *} \\
(0.00324)\end{array}$ & $\begin{array}{c}0.00791^{* * * *} \\
(0.00187)\end{array}$ & $\begin{array}{c}0.00222^{* * *} \\
(0.000745)\end{array}$ & $\begin{array}{c}0.00463^{* * * *} \\
(0.00142)\end{array}$ & $\begin{array}{c}0.00801^{* * *} \\
(0.00240)\end{array}$ \\
\hline $\operatorname{ProcInn}_{i, t-1}$ & $\begin{array}{c}0.0292^{* * *} \\
(0.00388)\end{array}$ & $\begin{array}{c}0.0126^{* * * *} \\
(0.00210)\end{array}$ & $\begin{array}{c}0.00207^{* * *} \\
(0.000724)\end{array}$ & $\begin{array}{c}0.00342^{* *} \\
(0.00134)\end{array}$ & $\begin{array}{l}-0.00351 \\
(0.00247)\end{array}$ \\
\hline $\log \left(a g e_{i, t}\right)$ & $\begin{array}{c}0.0246^{* * *} \\
(0.00260)\end{array}$ & $\begin{array}{c}0.00475^{* * *} * \\
(0.00152)\end{array}$ & $\begin{array}{c}-0.00350^{* * * *} \\
(0.000619)\end{array}$ & $\begin{array}{c}-0.0129^{* * *} \\
(0.00126)\end{array}$ & $\begin{array}{c}-0.0386^{* * *} \\
(0.00189)\end{array}$ \\
\hline $\operatorname{group}_{i, t}$ & $\begin{array}{c}0.0193^{* * *} \\
(0.00350)\end{array}$ & $\begin{array}{c}0.00609^{* * * *} \\
(0.00187)\end{array}$ & $\begin{array}{c}-0.00225^{* * *} \\
(0.000832)\end{array}$ & $\begin{array}{l}-0.00251^{*} \\
(0.00136)\end{array}$ & $\begin{array}{c}-0.00941^{* * *} \\
(0.00242)\end{array}$ \\
\hline Constant & $\begin{array}{c}-0.444^{* * *} \\
(0.0130)\end{array}$ & $\begin{array}{c}-0.193^{* * *} \\
(0.0168)\end{array}$ & $\begin{array}{c}-0.0871^{* * *} \\
(0.00447)\end{array}$ & $\begin{array}{l}-0.0172^{*} \\
(0.00884)\end{array}$ & $\begin{array}{c}0.0924^{* * *} \\
(0.0232)\end{array}$ \\
\hline Industry dummies & YES & YES & YES & YES & YES \\
\hline Year dummies & YES & YES & YES & YES & YES \\
\hline Observations & 34,521 & 34,521 & 34,521 & 34,521 & 34,521 \\
\hline Pseudo R-squared & 0.029 & 0.034 & 0.032 & 0.029 & 0.019 \\
\hline
\end{tabular}

Notes: Robust clustered standard errors in parentheses $* * * \mathrm{p}<0.01,{ }^{* *} \mathrm{p}<0.05, * \mathrm{p}<0.1$ 
Table A18: Quantile regression - Lagged innovation variables

\begin{tabular}{|c|c|c|c|c|c|}
\hline & (1) & (2) & (3) & $(4)$ & $(5)$ \\
\hline Quantile & .15 & .30 & .50 & .70 & .85 \\
\hline$G_{i, t-1}$ & $\begin{array}{c}0.0671^{* * *} \\
(0.00952)\end{array}$ & $\begin{array}{c}0.0375^{* * *} \\
(0.00619)\end{array}$ & $\begin{array}{c}0.00644^{* * *} \\
(0.00218)\end{array}$ & $\begin{array}{c}0.0132^{* * *} \\
(0.00376)\end{array}$ & $\begin{array}{c}-0.0122 \\
(0.00885)\end{array}$ \\
\hline $\operatorname{ProdInn}_{i, t-1}($ goods $)$ & $\begin{array}{c}0.0141 * * * \\
(0.00371)\end{array}$ & $\begin{array}{c}0.00720^{* * *} \\
(0.00196)\end{array}$ & $\begin{array}{l}0.00210^{* *} \\
(0.000818)\end{array}$ & $\begin{array}{c}0.00386^{* *} \\
(0.00153)\end{array}$ & $\begin{array}{c}0.00560^{* *} \\
(0.00266)\end{array}$ \\
\hline ProdInn $_{i, t-1}$ (services) & $\begin{array}{c}0.00354 \\
(0.00481)\end{array}$ & $\begin{array}{c}0.00242 \\
(0.00261)\end{array}$ & $\begin{array}{c}0.00116 \\
(0.00115)\end{array}$ & $\begin{array}{c}0.00357 \\
(0.00251)\end{array}$ & $\begin{array}{l}0.00792^{*} \\
(0.00428)\end{array}$ \\
\hline ProcInn $_{i, t-1}$ (methods) & $\begin{array}{c}0.0202^{* * *} \\
(0.00365)\end{array}$ & $\begin{array}{c}0.00973^{* * *} \\
(0.00193)\end{array}$ & $\begin{array}{c}0.00140^{*} \\
(0.000733)\end{array}$ & $\begin{array}{c}0.00147 \\
(0.00130)\end{array}$ & $\begin{array}{c}-0.00548^{* *} \\
(0.00251)\end{array}$ \\
\hline ProcInn $_{i, t-1}$ (logistics) & $\begin{array}{l}0.000452 \\
(0.00468)\end{array}$ & $\begin{array}{c}0.00139 \\
(0.00226)\end{array}$ & $\begin{array}{l}0.000268 \\
(0.00115)\end{array}$ & $\begin{array}{r}-0.000297 \\
(0.00187)\end{array}$ & $\begin{array}{c}0.00245 \\
(0.00356)\end{array}$ \\
\hline ProcInn $_{i, t-1}($ auxiliary $)$ & $\begin{array}{c}0.00844^{* *} \\
(0.00372)\end{array}$ & $\begin{array}{c}0.00226 \\
(0.00198)\end{array}$ & $\begin{array}{c}0.000982 \\
(0.000815)\end{array}$ & $\begin{array}{c}0.00237 \\
(0.00147)\end{array}$ & $\begin{array}{l}-0.00140 \\
(0.00268)\end{array}$ \\
\hline $\log \left(a g e_{i, t}\right)$ & $\begin{array}{c}0.0248^{* * *} \\
(0.00259)\end{array}$ & $\begin{array}{c}0.00437^{* * *} \\
(0.00154)\end{array}$ & $\begin{array}{c}-0.00364^{* * *} \\
(0.000626)\end{array}$ & $\begin{array}{c}-0.0128^{* * *} \\
(0.00127)\end{array}$ & $\begin{array}{c}-0.0382^{* * *} \\
(0.00203)\end{array}$ \\
\hline group $_{i, t}$ & $\begin{array}{c}0.0174^{* * *} \\
(0.00354)\end{array}$ & $\begin{array}{c}0.00600^{* * * *} \\
(0.00186)\end{array}$ & $\begin{array}{c}-0.00238^{* * *} \\
(0.000839)\end{array}$ & $\begin{array}{c}-0.00256^{*} \\
(0.00134)\end{array}$ & $\begin{array}{c}-0.00976^{* * *} \\
(0.00260)\end{array}$ \\
\hline Constant & $\begin{array}{c}-0.373^{* * *} \\
(0.0123)\end{array}$ & $\begin{array}{c}-0.158^{* * *} \\
(0.0168)\end{array}$ & $\begin{array}{c}-0.0773^{* * *} \\
(0.00461)\end{array}$ & $\begin{array}{c}0.0143 \\
(0.00899)\end{array}$ & $\begin{array}{l}0.121^{* * *} \\
(0.0235)\end{array}$ \\
\hline Industry dummies & YES & YES & YES & YES & YES \\
\hline Year dummies & YES & YES & YES & YES & YES \\
\hline Observations & 34,521 & 34,521 & 34,521 & 34,521 & 34,521 \\
\hline Pseudo R-squared & 0.029 & 0.034 & 0.032 & 0.029 & 0.018 \\
\hline
\end{tabular}

